4 nordon 



\section{Environmental Technology and Innovation Drivers and Policy Measures}

Summary notes from the NMRIPP Conference, Copenhagen, 2-3 September 2008 
Environmental Technology and Innovation Drivers and Policy Measures

Summary notes from the NMRIPP Conference, Copenhagen, 2-3 September 2008

TemaNord 2010:550

(C) Nordic Council of Ministers, Copenhagen 2010

ISBN 978-92-893-2080-1

Cover photo: Image Select

This publication is available as Print on Demand (PoD) and can be ordered on

www.norden.org/order. Other Nordic publications are available at www.norden.org/en/publications.

Nordic Council of Ministers

Ved Stranden 18

DK-1061 København K

Phone (+45) 33960200

Fax (+45) 33960202

\section{Nordic Council}

Ved Stranden 18

DK-1061 København K

Phone (+45) 33960400

Fax (+45) 33111870

www.norden.org

\section{Nordic co-operation}

Nordic co-operation is one of the world's most extensive forms of regional collaboration, involving Denmark, Finland, Iceland, Norway, Sweden, and three autonomous areas: the Faroe Islands, Greenland, and Åland.

Nordic co-operation has firm traditions in politics, the economy, and culture. It plays an important role in European and international collaboration, and aims at creating a strong Nordic community in c strong Europe.

Nordic co-operation seeks to safeguard Nordic and regional interests and principles in the global community. Common Nordic values help the region solidify its position as one of the world's most innovative and competitive. 


\section{Content}

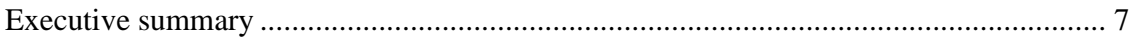

Create sound and updated environmental technology verification standards .................. 8

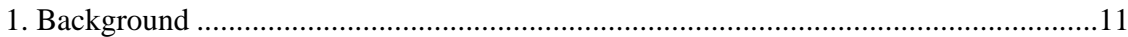

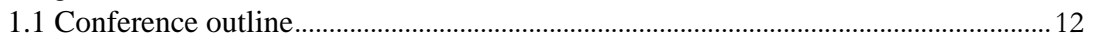

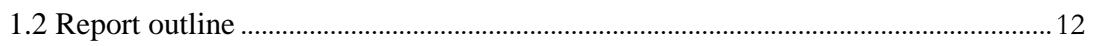

2. Key Messages from the NMRIPP Conference ..............................................................13

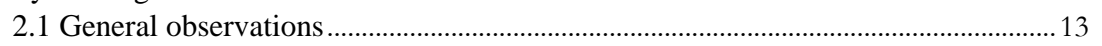

2.2 General policy guidelines..................................................................................... 16

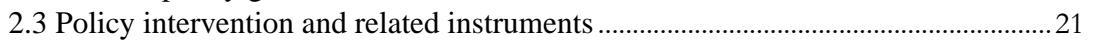

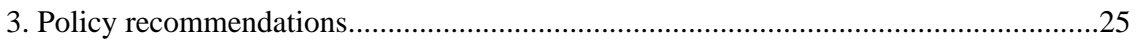

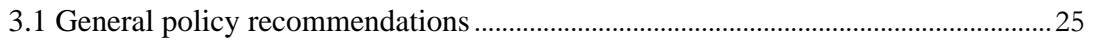

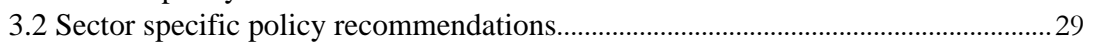

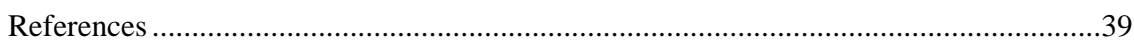

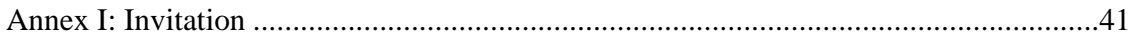

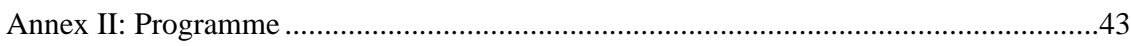

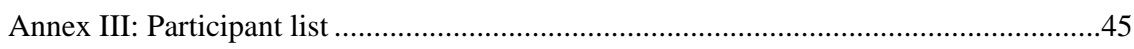

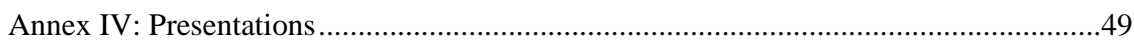

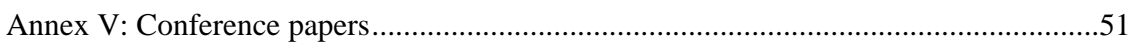

I. How can public authorities encourage Ecodesign? ....................................................... 51

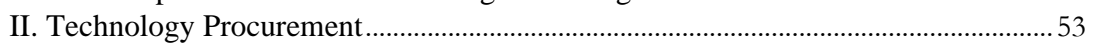





\section{Executive summary}

This report compiles summary notes of the NMRIPP Conference on "Environmental Technology and Innovation - Drivers and Policy Measures", held from 2-3 September 2008 in Copenhagen. The NMRIPP Conference was held as a concluding event of the Green Market and Clean Technologies (GMTC) project. Starting in 2006, the GMTC project has been conducted by four Nordic research institutions and is funded by the Nordic Council of Ministers Working Group for Integrated Product Policy (NMRIPP). The overall aim of the GMTC project has been to provide analysis of the ways in which the development and diffusion of environmental technologies can be enhanced. Key publications originating from the GMTC project include three sector reports covering (1) the building sector, (2) the pulp and paper sector, and (3) the mobile phone sector, as well as one synthesis report outlining investigations and lessons in sector specific and general environment and innovation policy for cleaner technologies.

In this context, the concrete aim of the 2008 NMRIPP Conference was to present and discuss Nordic and global experiences on drivers and challenges for environmental innovations in different sectors and to discuss the role and implications of public policy to facilitate environmental technology and innovation. Approximately 70 participants representing Nordic governmental, business and research organisations attended the conference. This report summarizes the presentations and discussions of the NMRIPP Conference. In the report key messages from the conference are distinguished into (1) general observations, (2) general policy guidelines, and (3) specific instruments for policy intervention. Based on the publications of the GMTC project and the presentations and discussion at the conference, the report formulates recommendations for policy action to enhance the diffusion of cleaner technologies and environmental innovation.

Drivers and barriers for environmental innovation were discussed from different perspectives, including (1) the need to reduce the risks associated with cleaner technologies, (2) the importance of co-benefits along the value chain to facilitate market success of cleaner technologies, (3) the fact that cost and price will always remain a dominant parameter, and (4) the importance of taking a system perspective and a system approach for the promotion and market penetration of certain cleaner technologies.

A number of policy instruments for the support of environmental innovation and cleaner technologies were discussed more in detail. These included (1) support for R\&D, (2) regulation, (3) eco-labelling, (4) green public procurement including technology procurement, and (5) legitimization of new technologies through incorporation into technical standards and norms. Other discussions revolved around the relationship between and within go- 
vernmental and non-governmental actor groups, the need to align and harmonize policies, as well as the importance of long-term strategies in policy making.

Based on the publications of the GMTC project as well as the presentations and discussion at the conference, the following policy recommendations to support environmental innovation and the diffusion of cleaner technologies can be given.

\section{Create sound and updated environmental technology verification standards}

Promoting "environmental technology" requires some form of verification that distinguishes and delineates the "cleaner" technology from a "conventional technology". This, however, can be difficult as (1) specific technology tends to have a variety of negative and positive environmental impacts and (2) verifications require regular revision and update, especially in highly innovative sectors.

\section{Create long-term and consistent policy environments}

The creation of long-term public policies and strategies that are foreseeable and reliable for producers, consumers and investors are likely to reduce the non-technical risks for these actors. Hence environmental innovation will benefit from consistent and long-term public policy environments based on long-term environmental goals and having the support across a broad political and societal spectrum.

Create a market environment that reflects the external costs for resource use and waste disposal

Creating a market environment that reflects the external costs for resource use and waste disposal can reduce or even eliminate the need for environmental technology verification with its inherent difficulties. In such market environments where prices reflect the true cost of resource use and environmental degradation, environmental technologies will inherently be more competitive. Thus, it is suggested to gradually but systematically increase the cost for resources and energy as well as emissions and waste disposal through market-based instruments such as green taxes and/or tradable allowance schemes.

\section{Align and harmonize policies}

The need to align environmental and innovation policy was highly emphasised at the NMR-IPP Conference. This can be achieved facilitated through: 
- the systematic, consistent and coordinated inclusion of environmental criteria into innovation frameworks and policies and promote the "Nordic voice" in EU and coordinate and influence positions e.g. through ETAP.

- the promotion of collaboration across ministries to facilitate dialogue and working towards the same goal. The creation of specific routine, platforms and networks to facilitate this policy dialogue across ministries and different administrative levels.

- the ex-ante evaluation of new policies, also assessing the impacts and side-effects of these policies on other sectors.

- closer links between Nordic and EU research and innovation programmes in order to develop research projects that suggest new mechanisms for ensuring more sustainable innovation approaches for the future.

\section{Maintain and develop a high-quality education system}

High quality education systems are crucial for providing highly skilled human resources. Maintenance and further nourishment of the knowledge base in the Nordic countries, accompanied by the interaction between the universities and the industry, would contribute to furthering innovation activities within and outside of the region. A suggestion for a specific action is to incorporate some form of environmental education into every education curricula.

\section{Promote multi-disciplinary approaches}

Solving environmental problems through more radical innovations will require multidisciplinary approaches that combine knowledge and experiences from a diversity of fields. As such, well directed innovation policies, such as inter-industry research programmes, experience centres, and researcher and staff mobility programmes, may be beneficial to the development of environmental innovations.

\section{Promote cross-border collaboration}

Especially in those sectors where research activities and collaboration often occurs in a national context, increased cross-border cooperation at a Nordic level and beyond represents opportunities to strengthen the innovation potential of these sectors. The public support of multi-national research programmes and international researcher and staff mobility programmes may stimulate cross-border collaboration and provide an arena for new ideas and thinking, exchange of knowledge and experiences including the further dissemination of best practices. 


\section{Consider joint export promoting activities}

Nordic joint export promoting activities of environmental technologies may not be only beneficial from an economic perspective but an increase of production and sales may gradually also result in "economies of scale" which is likely to improve the competitiveness of environmental technologies, both in the Nordic countries as well as on global markets.

Evaluate policy interventions to a wider extent, both from an ex-ante and ex-post perspective

It is recommended to evaluate environmental policies to a much wider extent. Ex post evaluation allows to assess the effectiveness of existing measures in meeting their environmental objectives and consequently the process of policy making can be improved. Ex ante evaluation can be an important tool to compare different policy alternatives, including the alternative of no action. Ex-ante evaluation may in particularly be relevant for the assessment of temporary limited policy incentives that seek to create markets for environmental technologies. Here it should be carefully assessed in an ex-ante perspective whether these technologies are able to compete in the market after the temporary policy incentive is phased out.

\section{Expand green public procurement}

With regard to green public procurement the following policy recommendations were suggested at the conference:

- Implement national action plans for procurement, clearly stating the ambitions and objectives of public procurement.

- Establish a separate, independent organisation for procurement.

- Identify sectors for public procurement and incorporate environmental elements. Suitable sectors for "green" public procurement include those where public procurement has a high market share and at the same time the environmental impact is significant.

- Incorporate life-cycle cost thinking to a wider extent into public procurement.

- Educate public purchasers on the legal possibilities and limitations.

- Disseminate best practices on public procurement.

- Follow-up and evaluate public procurement programmes.

\section{Sector specific policy recommendations}

The report concludes with sector specific observations and policy recommendation for the mobile phone sector, the building sector, as well as the pulp and paper sector. 


\section{Background}

This report compiles summary notes of the Conference ${ }^{1}$ on "Environmental Technology and Innovation - Drivers and Policy Measures”, held from 2-3 September 2008 in Copenhagen and being part of the 2008 Copenmind Conference. The NMRIPP Conference was attended by approximately 70 participants representing Nordic governmental, business and research organisations active in the wider field of environmental protection and innovation.

The NMRIPP conference was held as a concluding event of the Green Market and Clean Technologies ${ }^{2}$ (GMTC) project. Starting in 2006, the GMTC project has been conducted by four Nordic research institutions ${ }^{3}$ and is funded by the Nordic Council of Ministers Working Group for Integrated Product Policy (NMRIPP). The overall aim of the GMTC project has been to provide analysis of the ways in which the development and diffusion of environmental technologies can be enhanced. This should particularly be seen in the light that many cleaner technologies are available but their market diffusion is low.

Key publications originating from the GMTC project include three sector reports ${ }^{4}$ and one synthesis report ${ }^{5}$ outlining investigations and lessons in sector specific and general environment and innovation policy for cleaner technologies. The reports also draw policy barriers and drivers, illustrating areas of innovation policy improvement.

In addition to the four GMTC reports, the results of two additional studies initiated and financed by the Nordic Council of Ministers were presented at the NMRIPP Conference. These studies investigated (1) “Technology

\footnotetext{
${ }^{1}$ subsequently referred to as "NMRIPP Conference"

${ }^{2}$ Within the GMTC project, cleantech, cleaner technologies, or environmental technologies have been defined as "all technologies whose use is less environmentally harmful than the relevant alternatives".

${ }^{3}$ The collaboration for the GMCT research project was between the International Institute for Industrial Environmental Economics (IIIEE), Lund University, The Finnish Environmental Institute (SKYE), The Department of Development and Planning, Aalborg University and Risø National Laboratory, The Technical University of Denmark

${ }^{4}$ A) Emtairah, T., Tojo, N., Thidell, Å, Rozite, V. and Hayes, M. 2008. The challenges of energy efficiency innovations in the Nordic building sector: Green markets and cleaner technologies (GMCT). TemaNord 2008:566. Copenhagen: Nordic Council of Ministers. B) Kivimaa, P., Kautto, P., Hildén, M. and Oksa, J. 2008. What drives environmental innovations in the Nordic pulp and paper industry?: Green markets and cleaner technologies (GMCT). TemaNord 2008:566. Copenhagen: Nordic Council of Ministers. C) Remmen, A, Dirckinck-Holmfeld, K., Braun, C., Andersen, J., Kræmer, T.-P. The Nordic mobile phone industry - environmental innovations and policy instruments. TemaNord 2008:564. Copenhagen: Nordic Council of Ministers.

${ }^{5}$ Hayes, M. et al. 2008. Innovation Systems and Environmental technologies: Cross-sectoral analysis and policy implications. TemaNord 2008:565. Copenhagen: Nordic Council of Ministers
} 
procurement”" and (2) "How central authorities can support ecodesign"7 . A summary of these reports are presented in Annex V and key findings have been incorporated into the policy recommendations of this report.

In this context, the concrete aim of the 2008 NMRIPP Conference was to present and discuss Nordic and global experiences on drivers and challenges for environmental innovations in different sectors and to discuss the role and implications of public policy to facilitate environmental technology and innovation. During the conference speakers and other participants were asked to comment and challenge the findings and recommendations in the GMCT synthesis report and recommendations.

\subsection{Conference outline}

The conference was organised as a set of speeches and presentations, each followed by questions, answers and open discussion. At the end of the conferences key messages obtained during the conference were presented and the audience provided additional comments and feedback on these messages. A list of participants and the NMRIPP Conference programme is given in Annex II of this report. All conference sessions were moderated by Stig Hirsbak.

\subsection{Report outline}

This report summarizes the presentations and discussions of the NMRIPP Conference.

Section 2 presents the key messages categorized into thematic areas, describing ideas and messages at the conference noting general agreement or disagreement. The section also summarises key drivers and barriers for environmental innovation as presented and discussed at the conference.

Section 3 compiles the information from the preceding and formulates policy recommendations.

\footnotetext{
${ }^{6}$ Bauer,B., Larsen, B., Bode,B., Standley, M., Stigh, L. 2008. Technology procurement. TemaNord 2008:567. Copenhagen: Nordic Council of Ministers

${ }^{7}$ Jöbrink, A.-K., Melin, H.E. 2008. How central authorities can support ecodesign. TemaNord 2008:569. Copenhagen: Nordic Council of Ministers
} 


\section{Key Messages from the NMRIPP Conference}

This section summarizes the key messages obtained from presentations and discussion at the NMRIPP Conference. For the purpose of this report, key messages are distinguished into (1) general observations, (2) general policy guidelines, and (3) specific instruments for policy intervention.

In the following summary notes, key messages from the GMTC sector presentations (pulp and paper, buildings, mobile phones) are only to that extent presented when they generated discussion among the conference participants. For full details, it is suggested to consult the GMTC synthesis report and/or the three GMTC sector reports.

\subsection{General observations}

During the NMRIPP Conference, the following messages assisted in understanding the wider scene for cleaner technologies and relations with and among stakeholders.

\subsubsection{Reducing the risks}

During the conference, the matter of risk as a constraint to development and commercialisation of cleantech technologies was discussed from different perspectives. This included (1) private consumers as well as institutional purchasers such as municipalities being risk adverse to purchase cleantech products that have not been widely tested on the market, (2) potential investors into cleantech companies, and (3) (potential) developers and producers of cleantech products who - due to uncertainties about the market potential and success - are risk adverse to investing into $R \& D$.

From a customer's perspective, the topic of risk adversity of municipalities was discussed more in depth during the presentation on "Innovation incentives towards stronger markets” (Jon Söderström). The fact that many cleaner technologies have been available for many years, but have not reached considerable market diffusion has further increased the perception of potential risks attributed with cleaner technologies.

From an investor's perspective, interest into environmental technologies has been described as problematic since venture capitalists tend to be particularly conservative when investing private equity capital.

From the perspective of industry as a developer of innovative environmental technologies, (1) high costs for R\&D into innovative products, (2) 
unclear demand from industry and consumers, and (3) a funding gap for $R \& D$ activities were described to form major constraints and risks to invest resources into the development of innovative environmental technologies. In this context, publicly funded research and other schemes for investment had helped in the past to reduce these risks and consequently facilitated the development of cleaner technologies. Among the three sectors investigated by the GMTC project, especially the building sector was described to be risk adverse towards adopting environmental innovations.

In order to deal with these risks several ideas were proposed. Firstly, it was suggested that public policy and management is needed to either support the taking of risk or deal with the disproportional risk associated with environmental technologies. Such sharing or balancing of risk would facilitate the acceptance of innovative environmental technologies among industry and consumers.

The second approach in an industry perspective would be the acceptance of the risk and normalizing ideas of high risk into business decisions by allocating a certain percentage allocated to 'risky' ventures, as practiced in some industries like the mobile phone. Radical innovation comes with high risk, and acceptance can facilitate innovation.

\subsubsection{Importance of co-benefits}

Several speakers emphasised that environmentally advantageous processes and products are likely to only diffuse at a larger scale if there are other benefits for actors along the value chain, and in particular for customers. These co-benefits (also described as multiple benefits) help drive actors along the value chain to develop, produce, buy and eventually use cleaner technologies.

For instance customer benefits such as less energy consumption or better functionality are the key drivers that make out the market success of so-called "eco-design products". Increased sales and increased (or a least stabilized) market shares are key drivers for companies to engage in "eco-design". Another example refereed to the building sector where co-benefits/multiple benefits across the whole value chain were important for the diffusion of environmental innovations in the sector. Examples for these co-benefits included amongst others functional benefits, cost savings, meeting regulations, and becoming industry leaders. Another example was industrial symbiosis as it is practised in Kalundborg, Denmark. Demonstrating and recognizing the cobenefits of cleaner technologies have been crucial for implementing industrial symbiosis systems.

\subsubsection{Price/cost as the dominant parameter}

There was widespread agreement that price (from the perspective of the customer) and/or costs (from the perspective of the producer/user) is a do- 
minant parameter determining the success for cleaner technologies in the market. Cleaner technologies are not likely to penetrate markets to a larger extent, unless they are cost-competitive with current processes, products and service systems. Price and high cost of cleaner technologies was mentioned as an impeding presentation designs on eco-design.

Showing that costs could be saved through investments into cleaner technologies generally acted as a fast driver, especially in the private sector. On the other hand, the components for eco-designed products were described to often be more expensive, especially in the mobile phone sector. High product development cost for environmental innovations can be a key barrier for bringing environmental technologies into the market.

When private and public organisations purchase products and services, price is a determinant factor and most will make the choice that is cheaper, last but not least due to the fact that many employees are trained in this process. The principles of life-cycle-costing (LCC) are only to a limited extent applied by purchasers and users, which in particularly hinders the wider market penetration of cleaner technologies that come with higher investment cost but lower operating costs compared to those technologies currently dominate the market

Subsidies, loans, and grants were suggested to offer as a solution to promote environmental innovation and the adoption and uptake of new technologies. On the other hand, subsides were noted to have destroyed some cleantech markets, suggesting that caution should be exercised when considering this method. The potential of other market-based instruments such as green taxes in facilitating market access for cleaner technologies and "levelling the playing field" between "conventional” and "cleaner technologies" has only been addressed to a very limited extent at the conference.

\subsubsection{Taking a system perspective}

Several speakers emphasised the relevance of taking a system perspective and a system approach for the promotion and market penetration of certain cleaner technologies. In this context "systems" refer both to technical systems as well as socio-economic and organisational systems.

From a technology system perspective, difficulties in changing single technologies in a technology system can be difficult as this may disrupt the entire system, essentially locking in certain processes unless other parts of a process or a value chains are modified as well. This phenomenon was also described as "technology lock-in" and particularly observed in the pulp-andpaper sector and the building sector. For instance, in the latter, the integration of innovative heating, cooling and ventilation systems may require intervention into or change of the structure of buildings. This is particularly constraining the use of innovative environmental technologies when retrofitting existent buildings, but does also affect new buildings. 
Similarly, the importance of system thinking was also relevant to the mobile phone industry. Instead of only focussing on the end-user device/mobile phone, there is a need to focus on energy efficiency in the whole communication system. This issue was also brought up in the GMTC report on the mobile phone industry, where the potentials of an integrated systems approach for energy efficiency in a future $4 \mathrm{G}$ standard is discussed. Current policies affecting the mobile sectors such as the EU Code of Conduct on energy efficiency and IPP stakeholder discussions do not take a systems perspective which incorporates the whole communication system.

Systems should not only be understood as and limited to technical systems but as production and consumption systems in a wider perspective. In this context, it was suggested that innovation should not only refer to (technical) processes and products, but may also include innovative financing, operating and service schemes, such as contracting schemes in energy efficiency markets. Similarly, innovation can be seen from a business model perspective when organisations take a radically different approach in organizing themselves in order to increase market shares. In this perspective, technology is just an enabler. The case of the Kalundborg Industrial Symbiosis can be seen as another example of how organisational innovation rather than technical innovation entailed environmental benefits.

\subsubsection{Lack of awareness}

From the demand side of barriers, demand issues revolved heavily around the role of the consumer and how in many sectors demand for innovation of cleaner technology was simply not there or the consumer was disinterested (mobile sector). Complete lack and/or insufficient awareness on environmental issues were discussed as one of the key reasons for this lack of demand.

\subsection{General policy guidelines}

The following messages and general guidelines for policy makers relevant for the promotion of cleaner technologies were collected during the conference.

\subsubsection{Actor relationships}

Many discussions revolved around the roles of different actor groups, their relations to each other as well as relations within the different actor groups. The most widely discussed actor groups were government and industry/business but also research organisations, consumer, NGO's and the general public. In general there was widespread agreement that combining ac- 
tors, expanding their roles and forging cooperation were viewed as being very positive for fostering environmental innovation.

The GMTC research project confirms the importance of collaboration among different actor groups. Collaboration should be (1) multidisciplinary, (2) cross-sectoral, and (3) business-to-non-business. It was also stated to be important to create a common vision among different actors and the public on the future. This partnership is required to focus on tomorrow's problems.

Government - industry relationships

In his opening speech, the Danish Environment Minister, Troels Lund Poulsen promoted a shift from the traditional perspective with government as a regulator and the industry as a profit maker towards a partnership between industry, consumers, research and government. In his speech Mr Poulsen emphasized the important role of industry as being an important driver for environmental innovations. The government's role is seen as to provide environmental targets which then should be achieved in a partnership with industry. The actor structure and collaboration are crucial and policy should identify these relationships, not limited to industry and government but also non-governmental, European Union, consumer and other positive stakeholder relationships.

In general there was the view that if researchers, public officials and industries pull into the same direction, the risk that is perceived to come with environmental innovations will be reduced. It was suggested that close collaboration is necessary and sectors that are ready for this type of collaboration and these areas where actors mesh together should be actively identified and pursued.

A better knowledge among public officials about the industries/businesses they see over was considered to be crucial for the development of better policies. In this context it was stated that different industry sectors have different business models, these differences should be acknowledged and considered in policy making. Current environmental policy making is based on a limited understanding of government on the innovation dynamics in different industrial sectors.

\section{Government - government relationships}

Within the governmental sectors, many discussions focussed on relationship of actors between actors at (1) different administrative levels, in particular the National level and the EU level, and (2) between governmental actors in different areas of responsibility (e.g. environment, economy, energy, agriculture, education).

The relevance of political commitment was discussed relating to municipal, member state and European Union leadership for innovation ventures during a presentation on European industrial perspectives for Innovation incentives. In this context, some speakers emphasised the importance of 
having political support from National governmental leaders in addition to supportive roles from the European Union. Also, policies brought forward and established by the European Commission, but lacking National support are likely to remain ineffective.

More insight into the issue of government-government relationships is provided in Section 2.2.2 Policy interaction and alignment.

Industry - industry relationships

Close relationships between different industry actors are perceived positive to stimulate innovation. For instance it was emphasized for the building sector stable alliances of architects, builders and research are crucial to further diffuse environmental technologies. In particular, architects should be involved in a very early stage. Also, good links between SME's and bigger companies are considered important to foster innovation.

Industry - research relationships

Not surprisingly, close relationships between industry and research organisations such as universities were perceived to be very positive and crucial for innovation. In the pulp and paper sector very strong ties between industry and universities and a common frame of references with the workforce were crucial for environmental innovations. On the contrary, in the building sector links between industry and universities were described to be relatively weak.

Involvement of the public

A dialogue with and involvement of the public into decision making, on an international level, was perceived to be important. Also, a positive attitude of the public towards science and technology was declared to be crucial to maintain long-term competitiveness.

\subsubsection{Policy interaction and alignment}

Discussion on the need to harmonize and align policies revolved around two different dimensions, (1) harmonization of policies between different administrative levels, and (2) the alignment of policies between different areas of responsibility.

Throughout the conference, there was widespread agreement that innovation and environmental policy are not well integrated or merged. Innovation policy is largely nationally focused, whereas environmental policy is increasingly becoming supranational (EU/global) making integration difficult. Therefore, to promote environmental innovation, alignment of environmental and innovation targets are needed. This also requires coordinating of national policies with those at the EU level.

A recent example where cleaner technologies receive strong recognition in innovation policy is the Lead Market Initiative (LMI) for Europe which was 
launched by the European Commission following the EU's 2006 broad based innovation strategy. In general, the LMI seeks to set up a demand-side policy framework that promotes the quick uptake of innovations by implementing a number of 'instruments' or policy initiatives. These instruments are tailored to bring down barriers for innovative goods and services in six market areas. Four out of the six first market areas of the LMI include specifically cleaner technology areas and include (1) sustainable construction, (2) innovative use of renewable raw materials for bio-based products, (3) proper and effective waste management and recycling, and (4) renewable energy sources. Policies under the LMI are grouped in the following categories; legislation, public procurement, standardisation, labelling, certification and lastly, complementary activities (mainly business and innovation support services, training and communication and financial support and incentives). Further information on the Lead Market Initiative can be accessed at http://ec.europa.eu/enterprise/ leadmarket/leadmarket.htm.

At the conference it was discussed that it is important to collaborate among ministries and to work together towards the same aim. In general, alignment of polices between different areas of responsibility can be beneficial for environmental innovation. For instance, experience from the pulp and paper industry indicated that if environmental policies, technology policies and other sectoral policies such as energy, transport and agriculture are directing into the same direction, the effects for environmental innovation can be very positive.

The need to evaluate on how to combine different policy instruments to be effective was also brought forward. The GMTC research project has identified a set of policies that in the past worked well in promoting environmental innovation. However, based on these experiences, it was perceived to be difficult to generalise policy recommendations as it always depends on how policies have been implemented.

An example of how certain policies constrained environmental innovation in the past was the European procurement tender directive, focussing only on price as the sole criterion in the tender process without incorporating environmental criteria. This has in particularly relevant for the construction sector. The regulation has changed in 2007 and allows now the inclusion of environmental criteria. However, many purchasers are not aware of this yet.

In addition, the inflexibility of policy as well as policies that tends to support outdated solutions was a barrier identified in the cases of the pulp \& paper and mobile phone industries.

\subsubsection{Importance of long-term strategies}

Several speakers highlighted the importance of creating a long term visions and implementing long-term strategies for fostering environmental innovations. This has been discussed from different perspectives. 
Firstly, innovation and environmental polices that are consistent, reliable and have a long-term strategy reduce the risk for producers, investors and customers to engage in cleaner technologies. One example brought forward included feed-in tariff schemes such as the Renewable Energy Act in Germany, providing price guarantees for electricity produced from renewable resource over a 20 year period. The renewable energy act was crucial for the rapid growth of the German renewable energy industry as it provided favourable and reliable business climate, both from a producer's as well as from an investor's perspective, over a long time period.

When favouring certain technology it is also considered to be important to evaluate long-term consequences and understand the potential of other competing technologies. Also, future markets must be evaluated to support entrepreneurs and the changing climates around them.

Setting realistic long-term targets in policy making is important. This requires that strategies will need to think past election time frames if anything is to be achieved. It was also stated to be important to inform the public and policy about the long time frames that come along with the change of current production and consumption systems.

\subsubsection{Knowledge generation and distribution}

Knowledge being an important resource for innovation was widely discussed at the Conference. A good knowledge capital is a crucial resource for innovation and continuing to focus on good education is likely to pay off in the long term. It was also stated that there is a greater need for interdisciplinary knowledge. Consequently, education is highly necessary for preserving knowledge and innovation as well as being crucial for providing human resources within different sectors.

With regard to the distribution of knowledge, institutional knowledge transfer and transfer pools are needed, especially to avoid repetition. The challenge is to enable knowledge transfer between institutions; avoiding repetition and creating a knowledge transfer pool and recognizing the sector differences.

It was suggested to facilitate better networking of knowledge in the European Union, as well as being up to date and relevant for data and studies. Knowledge networks should become easier to access for actors, breaking down "red tape" comparable to the US where networks are much easier to subscribe to and useful.

Also, preventing knowledge lock-ins, loss of knowledge by sector and transfer within sector is needed. The building sector was brought up as one example where knowledge loss and insufficient knowledge distribution is a key barrier to the diffusion of environmental technologies. This is largely caused by the sector structure, high fluctuation and ageing of staff, the project orientation of the sector constraining the transfer of particularly tacit 
knowledge, as well as the lack of common knowledge pools facilitating transfer of knowledge.

Some discussion revolved around the evaluation of the effectiveness of R\&D spending. Current evaluation systems only focus on intelligent property knowledge as the key evaluation criteria, but not on tacit knowledge. It is recognized, however, that tacit knowledge is very difficult to measure. Nevertheless, tacit knowledge is important as it creates intellectual property knowledge and vice versa.

\subsection{Policy intervention and related instruments}

This section covers specific policy instruments for the promotion of cleaner technologies that were discussed during the NMRIPP conference.

A common topic in several discussions was the need for policy evaluation. Policies and innovation need a feedback loop, in order to correct mistakes in the past (through intervention theory) that checks the validity and how well policy is working.

\subsubsection{Supporting research and development}

There was strong consensus that public support for research and development is crucial to foster environmental innovations. It was discussed that in many sectors, however, research and development is under-funded, and structures around R\&D were inadequate in some cases (such as the building sector), while having served other sectors relatively well (such as public funding of the pulp and paper sector in Finland). In order to stay on top of innovation, research and development must be better funded, supported, more flexible while acknowledging the differences between sectors.

In particularly the necessity to make public support to research more flexible has been stated at several points. In this context, it has also been emphasized that the administrative burden and implicit rules of EU-funded and administered R\&D support programmes make things needlessly complicated for companies.

In a global context, the Nordic region is relatively small in comparison to other major economies. Thus, the available resources in the Nordic countries for research and development are relatively small and it is necessary to give priorities to certain areas to create strong research and innovation environments. Similarly, from an industry perspective it was it was suggested to focus on niche markets for environmental technologies.

\subsubsection{Regulation}

Regulation as a driver for environmental innovation was only discussed to a limited extent during the conference. 
From a Swedish industry perspective, a survey conducted among 15 Swedish companies revealed that, generally, regulations were perceived as a positive if they are long-term, harmonized, fair and consistent with other policy areas, avoiding legislation conflict. Industry association were described to be more conservative with regard to regulation, as they are obliged to represent the "lowest common denominator" of the branch.

It was suggested that best practice should guide legislation, and that hybrids of regulation and reward incentives will offer the most proactive solutions.

It was stated that in a globalized economy it becomes increasingly difficult for (national) governments to enact "good" regulatory legislation. The reason for this is that regulators may not have sufficient knowledge and understanding of the activities of business organisations operating in a global market. In this context, globally trades products such as mobile phones shall with to be established global standards, for instance on energy efficiency performance.

The status of small and medium enterprises (SME's) was discussed and catering to special regulations and legislation for them.

The building code was perceived as an important regulatory intervention that drove innovation and increased energy efficiency in the building sector. Particularly, the diffusion of insulation was mainly driven by regulation. The building code is still important but it may only speed up the diffusion of certain technologies.

\subsubsection{Eco-labelling}

The role of eco-labelling for promotion of environmentally advantageous products was widely discussed during the conference. Overall, there was a mixed view on the utility of eco-labelling in innovation and cleaner technology.

In particularly, the speeches and presentations of Anna-Karin Jönbrink covered eco-labelling and stimulated considerable discussion. A key message from a survey conducted among 15 Swedish companies was that none of these companies ever mentioned eco-labelling as being a relevant driver for the development of "eco-design" products. These finding can partly be attributed to the fact that for many especially low-volume) products no ecolabelling criteria/scheme have been developed. Hence, the applicability of eco-labels is often limited to high-volume products.

The effectiveness of eco-labels can be highly reliant on (environmental) trends and consumer behaviour that can change in some sectors very rapidly. Consumer behaviour and preferences are also highly reliant on economic cycles. In this sense it was suggested to not only rely on consumers alone to create and maintain markets for environmental products. 
It was discussed that certain types of eco-labels are more effective than others. The effectiveness of Type 1 eco-labels was perceived to be lower than for instance Type 2 labels.

Eco-labels were not perceived to be effective in rapid design sectors, such as the mobile phone sector.

It was also discussed that the standards of some eco-labels may not be very ambitious and rather eco-labels should only been awarded to the top performers ("the top 10\%") of the market.

It was recognized that in particularly for globally traded products, ecolabelling is also increasingly becoming a global issue.

Based on the discussion however, Ecolabels were still viewed as being useful based on their type (self-declared vs. verified) and the sector where involvement was present. It was stated, however, that eco-labelling could potentially be an area where the effects are not as great, and may divert funding from a more effective driver to innovation in cleantech.

\subsubsection{Procurement}

Public procurement as an instrument to create markets for cleaner technologies and products was extensively discussed during the conference. In particularly, the speeches and presentations of Bjørn Bauer and Lars Wärngård covered technology procurement (for new environmental technologies/nonof-the-shelf products and "regular" public procurement (for of-the-shelf products). Among the Nordic countries, technology procurement was described to be the most widespread in Sweden with about 100 cases so far; on the contrary, its use in Norway and Denmark has been rather limited yet. Technology procurement is perceived to address three key barriers to innovation, namely (1) high innovation cost, (2) lack of internal funding, and (3) lack of external funding.

Policy related to procurement should reflect the importance of leadership and the dialogue between buyers and sellers as well as facilitate the creation of institutions or organizations to overcome procurement barriers. It was discussed that making actors take risks in administration is a challenge and requires leadership and a dedicated organisational set-up. It was also suggested that budgets for public procurement in municipalities should be increased, as well as dealing with certain circles of conservatism.

It was stated that public procurement does often not support environmentally better products. Life Cycle Cost (LCC) thinking was perceived to be not sufficiently incorporated into public procurement practices.

It is important to identify sectors that are ready for public procurement and incorporate environmental elements into the procurement specifications. Suitable sectors for "green" public procurement include those where public procurement has a high market share and at the same time the environmental impact is significant. A Norwegian study identified three sectors as particu- 
larly suitable for green public procurement, among them buildings/construction and computers/IT.

Additionally, it was brought forward that public purchasers may need more education and training on the legislative possibilities of public procurement.

As opposed to environmental policies, the integration of innovation policy criteria into public procurement is perceived to be difficult as it is considered as national protectionism.

Municipalities were debated on this subject about their conservative nature in some countries and reluctance for environmental or 'green' procurement. Generally, municipalities in Nordic countries are more open to risk than the counterparts in North America.

How to increase public procurement budgeting and ask what micro and niche markets can be engaged for public procurement is a problem. Opening procurement to environmental criteria, and spreading the knowledge that it is open on a EU level is essential.

There is need for a National Action Plan for procurement, stating a clear aim and purpose that is harmonized with other areas. The ambitions of public procurement have to be clearly stated.

There is a need for a separate, independent organisation for procurement. In Sweden, Vinnova is proposing to establish a separate agency.

It was also stated that there is a need to follow-up and evaluate public procurements programmes.

\subsubsection{Technology legitimization and standards}

It was discussed that cleaner technologies have to be legitimate in order to find acceptance and consequently to enhance their diffusion. Certification of cleaner technologies from industry standards is an important step to enhance legitimization. Examples discussed included environmental technologies in the building sector.

The need for better flexibility of industry standards was a related topic that was discussed. Environmental technology needs certification from industry standards but there is also a need to change common industry standards and incorporate environmental aspects/requirements into them.

\subsubsection{Voluntary agreements and self-regulation}

At the Conference, voluntary agreements between industry and governments and industry self-regulation as a tool to promote environmental innovations were only addressed to a limited extent.

In the mobile phone industry, voluntary agreements such as the EU Code of Conduct on energy efficiency were perceived to be not very ambitions. IPP stakeholder discussions, however, helped to create a common knowledge platform in this sector. 


\section{Policy recommendations}

\subsection{General policy recommendations}

A general conclusion from the conference discussions is that the principals and functioning of markets for greener technologies/eco-design do not fundamentally differ from markets for "conventional" technologies. For the majority of consumers price and functionality are likely to remain the dominant parameters in their buying decisions. Only a limited segment of the market is likely to pay a premium for environmentally advantageous products, unless the product does also offer other functional benefits over a "conventional product / technology". Least-life cycle cost thinking is still insufficiently practiced in many markets, especially among private consumers.

Create sound and updated environmental technology verification standards

Often it can be difficult to clearly distinguish between an "environmental technology" and a "conventional technology". Typically, certain criteria such as "energy input per service unit" or "elimination of toxic materials" are used to delineate "environmental technology" from "conventional technology". However, specific technology tends to have a variety of negative and positive environmental impacts.

Verification in some format is definitely useful to promote the development of environmentally sounder technologies and products, but the format and application should be carefully considered. The danger of verification is that certain technological paths will be favoured as different types of environmental impacts (e.g. emission vs. biodiversity) cannot be objectively compared. The same technology may also have different environmental impacts in different localities, e.g. depending on what technologies it will replace and in which conditions.

As technologies and markets evolve these verifications require regular revision and update, otherwise they might constitute a barrier for innovation. The frequencies of these updates, however, depend on the innovation dynamics of the respective markets and technologies and thus may differ widely across different sectors. The administrative process for revision and update of environmental technology verification standards may, however, have difficulties to keep up with the developments of highly dynamic sectors such as the ICT sector. 


\section{Create long-term and consistent policy environments}

The creation of long-term public policies and strategies that are foreseeable and reliable for producers, consumers and investors are likely to reduce the non-technical risks for these actors. Consistent long-term public policies are particularly important for capital-intensive sectors with long investment cycles. In this context, it is also suggested that governments should communicate how and with which type of policy intervention they seek to achieve their long-term environmental goals. This applies particularly for regulatory interventions and market-based mechanisms that can fundamentally influence the economic conditions in markets.

Create a market environment that reflects the external costs for resource use and waste disposal

Creating a market environment that reflects the external costs for resource use and waste disposal can reduce or even eliminate the need for environmental technology verification with its inherent difficulties. In such market environments where prices reflect the true cost of resource use and environmental degradation, environmental technologies are inherently more competitive.

Thus, it is suggested to systematically increase the cost for resources and energy as well as emissions and waste disposal through market-based instruments such as green taxes and/or tradable allowance schemes. These additional costs shall reflect the external cost for resources and waste disposal that are currently not incorporated in market prices. It is crucial to gradually implement these changes as part of a long-term strategy which will give producers and consumers sufficient time to prepare and adapt.

Internalizing the external costs of resource and energy consumption as well as waste disposal and emissions will create and sustain markets for environmental technologies and products across all sectors. Internalizing external cost may also require new approaches, e.g. extended producer responsibility (EPR) schemes with regard to energy consumption. This may be particularly relevant in private consumer markets where often the up-front cost rather than life-cycle costs are a key purchasing criteria, hence impeding the market penetration of more energy-efficient technologies.

In general, market-based instruments as a tool for the creation of markets for environmental technologies were only discussed to a very limited extent at the NM-RIPP conference. 


\section{Align and harmonize policies}

The need to align environmental and innovation policy was highly emphasised at the NM-RIPP Conference. This can be achieved facilitated through:

- the systematic, consistent and coordinated inclusion of environmental criteria into innovation frameworks and policies and promote the "Nordic voice" in EU and coordinate and influence positions e.g. through ETAP

- the promotion of collaboration across ministries to facilitate dialogue and working towards the same goal. The creation of specific routine, platforms and networks to facilitate this policy dialogue across ministries and different administrative levels.

- the ex-ante evaluation of new policies, also assessing the impacts and side-effects of these policies on other sectors.

- link Nordic and EU research and innovation programmes in order to develop research projects that suggest new mechanism for ensuring a more sustainable innovations approaches for the future.

Maintain and develop a high-quality education system

There was widespread agreement at the NMR-IPP Conference that importance of a high quality education system is essential for providing highly skilled human resources. Maintenance and further nourishment of the knowledge base in the Nordic countries, accompanied by the interaction between the universities and the industry, would contribute to furthering innovation activities within and outside of the region. A suggestion for a specific action is to incorporate some form of environmental education into every education curricula.

\section{Promote multi-disciplinary approaches}

The importance of multidisciplinary approaches to solving environmental problems has been emphasized throughout the conference. Bringing more radical innovations to realisation will require combining knowledge and experiences from a diversity of fields. As such, well directed innovation policies, such as inter-industry research programmes, experience centres, and researcher and staff mobility programmes, may be beneficial to the development of environmental innovations.

\section{Promote cross-border collaboration}

Especially in those sectors where research activities and collaboration often occurs in a national context, increased cross-border cooperation at a Nordic level and beyond represents opportunities to strengthen the innovation potential of these sectors. The public support of multi-national research programmes and international researcher and staff mobility programmes may stimulate cross-border collaboration and provide an arena for new ideas and thinking, 
exchange of knowledge and experiences including the further dissemination of best practices.

\section{Consider joint export promoting activities}

Export-promoting activities on environmental technologies and energy technologies have been established by Nordic countries in the latest years in a number of instances. As some of the challenges on the globalizing markets are common for the countries, there can be advantages in making Nordic joint activities on this in selected product areas and sectors. Increasing export of environmental technologies may not be only beneficial from an economic perspective but an increase of production and sales may gradually also result in "economies of scale" which is likely to improve the competitiveness of environmental technologies, both in the Nordic countries as well as on global markets.

Evaluate policy interventions to a wider extent, both from an ex-ante and ex-post perspective

In general, it is recommended to evaluate environmental policies to a wider extent. A practical definition of the task of evaluating environmental policies is given in the $6^{\text {th }}$ Environmental Action Programme for the European Union (EP/EC 2002). Here, the objectives of evaluating environmental policies are formulated as:

"improvement of the process of policy making through: (1) ex ante evaluations of the possible impacts, in particular the environmental impacts, of new policies including the alternative of no action and the proposal for legislation and publication of the results; (2) ex post evaluation of the effectiveness of existing measures in meeting their environmental objectives.”

Environmental objectives can be achieved through different forms of policy intervention and ex ante evaluation can be an important tool to compare different policy alternatives, including the alternative of no action. Typical criteria used in environmental policy evaluation are environmental effectiveness, cost-effectiveness, economic efficiency, enforceability, flexibility and persistence of the effects, amongst others.

Ex-ante evaluation may in particularly be relevant for the assessment of temporary limited policy incentives that seek to create markets for environmental technologies. Here it should be carefully assessed in an ex-ante perspective whether these technologies are able to compete in the market after the temporary policy incentive is phased out. 


\section{Expand green public procurement}

With regard to green public procurement the following policy recommendations were suggested at the conference:

- Implement national action plans for procurement, clearly stating the ambi-tions and objectives of public procurement.

- Establish a separate, independent organisation for procurement.

- Identify sectors for public procurement and incorporate environmental elements. Suitable sectors for "green” public procurement include those where public procurement has a high market share and at the same time the environmental impact is significant. Buildings/construction and IT are two key sectors to start with.

- Incorporate life-cycle cost thinking to a wider extent into public procurement.

- Educate public purchasers on the legal possibilities and limitations.

- Disseminate best practices on public procurement.

- Follow-up and evaluate public procurement programmes.

\subsection{Sector specific policy recommendations}

The following sector specific policy recommendation will emphasize a much wider use of regulation where appropriate and possible as well market-based instruments such as green-taxes.

\subsubsection{Mobile-phone sector}

The most significant environmental issues in the life-cycle of mobile phones or mobile end-use devices are (1) high energy and resource consumption and the use of chemicals in production, (2) energy consumption during the use phase which includes electricity use for charging the mobile end-use device as well as for the operation of the network, and (3) end-of life management issues of the phone.

The RoHS directive on the phase-out of toxic chemicals and the upcoming EuP energy efficiency standards are the only public policies that have been or are expected to promoting environmentally advantageous mobile phones. Other instruments such as eco-labelling, public procurement and the WEEE directive for waste prevention have not contributed to any significant environmental innovation in the sector. In addition, certain environmental aspects such as the energy consumption in the network have not received any public attention at all yet.

There are a number of sector specific factors that exacerbate the use of environmental policies for promoting environmental innovations in the mobile phone sector. Similar to other ITC sectors, the mobile phone sector is 
characterized by (1) high innovation dynamics and short product cycles, (2) highly heterogeneous end-use devices incorporating multiple functions, (3) global supply chains, (4) global markets, (5) very competitive and pricesensitive markets for end-use devices, and (6) very low consumer awareness regarding the environmental performance of end-use devices as typically price, performance and design are the key purchasing criteria. Also, the current business model of the industry is focussed on continuous technology innovation and promotes the rapid replacement of phones on the market.

In particular, the high innovation dynamics of the sector and the highly heterogeneous product portfolio of the brandholders make it very difficult to establish and update environmental technology verification standards which would distinguish a "green" mobile phone from a "conventional" mobile phone. However, environmental technology verification standards are a key prerequisite for many of the traditional policy instruments such as ecolabels, public procurement, and energy performance standards.

The following discussion on policy interventions will focus on:

- Chargers (no-load energy consumption \& reuse)

- Use-phase energy consumption of the mobile end-use device

- Energy consumption of the network

- Energy and resource consumption in production

- End-of life management of mobile end-use devices

\section{Chargers}

The main potential for environmental innovation for mobile phone chargers is (1) the reduction of no-load losses through technological improvements and behavioural change and (2) the reuse of chargers when switching to a new mobile phone.

\section{Reduction of no-load losses through technical improvements}

No-load losses from chargers can be significantly reduced through technical improvements. The most effective policy intervention to achieve lower noload losses for new charger is a mandatory energy standard that is set at the level of best available technology, thereby taking least-life cycle cost for the user into account. Current voluntary agreements such as the EU Code of Conduct and the anticipated mandatory standards under the framework of the EuP Directive are not very ambitious to what would be technically feasible and economic efficient in an life-cycle perspective.

Despite this potential for further energy savings, the current average noload losses of chargers with switch mode technology are already fairly low at about 0.2 Watts. Policy makers should carefully assess the appropriateness of further intervention with regard to energy efficiency of mobile phone chargers and possibly prioritize and allocate their (limited) administrative resources to other products and sectors where the total potential for energy savings is much greater (e.g. buildings, appliances, cars). 


\section{Reduction of no-load losses through behavioural change}

Changing user's behaviour and encourage them to unplug the charger when the phone is completely charged would result in immediate energy savings. In this context Nokia's approach to display a message ("Battery is full. Please unplug charger") is simple and cost-effective and should become the standard across the whole industry. Eventually, it could help to establish a culture of unplugging chargers that could spread over to other devices. Policy makers should encourage the dissemination of such best-practises across the sector by supporting appropriate platforms and forums for dialogue and knowledge exchange.

\section{Re-use of chargers}

The introduction of a charger with a standardized interface to the mobile end-use device, which would allow the re-use of the charger across different brands, is not considered a realistic option for various technical, safetyrelated as well as branding-related reasons.

However, another option to encourage the re-use of charger is to sell chargers and mobile phones separately, which would only require brandholders to change logistics. Many mobile phone users stick to their brand when switching the phone and may in many cases be able to reuse their old charger.

\section{Mobile end-use devices}

In principal, developers and producer of mobile end-use devices have a strong incentive to design their mobile devices with a high level of energy efficiency as this will help to meet consumer demands for a long use phase without the need for recharging, respectively compact size and low weight by minimizing the battery. This customer needs driven incentive does, however, not apply to the charger and the network.

"Traditional" instruments that have been used to create a market demand pull for energy efficient electrical and electronic products are declarative and comparative energy labels, mandatory energy performance standards, and voluntary agreements. Labelling instruments have in particular been effective in promoting energy efficiency for certain mature and (relatively) homogenous product groups that are perceived by consumers as being significant energy consumers. Examples of these product categories include washing machines, dryers, as well as freezers and refrigerators. However, these instruments are by nature inflexible to rapid product development as the administrative process to establish and update power standards in mandatory energy performance standard schemes and labelling schemes is too slow in the very dynamic innovation environment of the mobile phone sector. Similarly, the high heterogeneity and complexity of mobile end-use devices in the market exacerbates the establishment of energy standards due to the difficulty of defining a functional unit.

In theory, a product-based energy tax, based on the device's energy consumption during the expected use-phase of the product would be a highly 
flexible policy instrument suitable to promote energy efficiency for mobile end-use devices and other ICT products. Such a product-based energy tax would incorporate extended producers responsibility (EPR) principles, it would internalize the external costs of electricity production, and give a direct incentive to producers to design more energy efficient products.

\section{Network}

The network infrastructure has been pointed out as significant energy user in the communication chain, but has received very little attention in terms of energy efficiency yet. The GMTC study on Environmental Innovations in the Nordic Mobile Phone Industry emphasizes the need to incorporate energy efficiency as critical design parameter into the next mobile communication standard (4G). The standard making process will require coordinated international action and it is suggested that the Nordic countries take a lead role in this, both in terms of the technical development as well as in pushing for energy efficiency aspects in the 4G standards itself. Nordic policy makers can facilitate this process by supporting relevant R\&D activities and energy efficient $4 \mathrm{G}$ pilot networks.

\section{Resource use and chemicals}

The RoHS directive illustrates the effectiveness of mandatory regulation in phasing out toxic chemicals in electronic products. High energy use and resource consumption and the subsequent high quantities of waste are an environmental issue across the entire electronics manufacturing industry. The potential for environmental innovation has not been further investigated in the GMTC studies. However, it is anticipated that environmental innovation with regard to resource use and chemicals in the electronic industry will be mostly supply-driven by supporting national and international R\&D activities in "green electronics".

\section{End-of life management}

End-of life management of mobile phones has not been further investigated in the GMTC studies. There is, however, agreement among industry and government on the need to build up lasting structures for the collection and recycling of mobile phones and other electrical and electronic products on a global scale.

\subsubsection{Building sector}

The building sector received particular attention in the discussions during the NMRIPP Conference. Several speakers emphasised that over the past two years, the building sector turned into the focus of attention of the environmental discussion, mainly due to their significant contribution to total energy consumption. This is considered to be particularly remarkable as many technologies to lower energy consumption of buildings have been 
available for many years but their market diffusion has been low. It has also been stated that the building sector has been neglected from public funding for many years.

Buildings are complex systems consisting of the building envelop and the inner space, building elements as well as water, air and energy systems. Buildings provide end users with numerous functions that are created by a range of actors with various interests. The building sector is characterised by interdependence and interaction of these actors who are working together on a project basis. Even though energy savings can be achieved radically through relatively simple changes in building construction, materials and application of energy efficient technologies; it is more challenging to realize these changes from an institutional perspective.

In the building sector, the building code has often been referred to as an influential regulatory intervention in energy efficiency improvements, especially when it comes to the diffusion of better insulation of the building envelope. Other instruments, such as the EU Directive on the Energy Performance of Buildings (2003) that resulted in the establishment of the certification system (energy declaration) for buildings for more apparent consumption patterns, as well as energy taxes, energy saving information and advice programmes, and investment and subsidy schemes are being used to reinforce the effort to integrate energy efficiency into building requirements. The effectiveness of these schemes has varied.

There are a number of sector specific characteristics shaping the possible policy intervention framework. The building sector is featured by a) low innovation dynamics and long product cycles, b) focus on construction costs with little concerns on running costs, c) split incentives for energy conservation, d) lack of data availability for calculating the buildings' lifetime costs, e) strong state intervention with regards to control and regulative involvement such as subsidies, taxes, guarantee loans, f) for consumers invisible energy costs of new buildings, and g) weak linkages between building firms and universities, research institutes. Typically, upfront cost and functionality under time pressure are the key contracting criteria on the building market. Due to these characteristics of the Nordic building sector, mostly demand driven policies for market creation are necessary that address all barriers simultaneously.

\section{Regulation and building codes}

Regulation and more stringent building codes can create long-term markets for energy efficient building technologies. In this context, building codes were claimed to be successful regulatory instruments in increasing energy efficiency in the building sector in the past. Typically, energy efficiency requirements are either integrated in the general building codes or standards for new buildings, or they are set as separate energy efficiency standards. These energy efficiency standards eliminate the least energy efficient buil- 
ding techniques from the market, but rarely give incentives to designers and builders to aim for much more ambitious energy performance in buildings.

Building codes and regulatory energy efficiency requirements can be an effective driver for higher energy efficiency, if more stringent energy efficiency standards are set and regularly updated in line with the changes of the continuously evolving construction market. The principles of least life cycle cost and economic efficiency should be applied in setting the energy efficiency standards of the building and/or the individual building technology. To increase acceptance for higher energy efficiency standards and the inherent higher upfront cost, it is suggested to provide positive incentives such as low-interest loans to builders for the incremental cost.

\section{Institutionalize energy efficient building techniques}

Due to the specific characteristics of the buildings sector, its project orientation and disperse employment structure, it is essential to institutionalize energy efficient building techniques and to include both demands (technical norms and standards) for the entire building (not only in case of new construction, but also of refurbishment) and for individual components on installation by replacement into the building code.

\section{Set dynamic, long-term energy efficiency targets}

As discussed above, the low innovation dynamics of the construction sector allows for setting more stringent energy efficiency performance targets; however these targets shall be announced in advance. The targets shall be supported by a long-term government strategy, where the projected goals and well-defined targets as well as future standard modifications are described and announced towards the industry. It provides then time to the actors in the building sector to develop feasible solutions on the most cost effective way as a response to the projected requirements. Setting stringent, dynamic and transparent targets and tightening the loose communication channels between state administration and industry is the underlying condition for industrial environmental innovation in the building sector.

\section{Ensure effective enforcement of energy efficiency standards}

Besides long-term planning and stringency, the implementation of tighter standards requires an effective enforcement mechanism in place for checking the energy performance of newly built/refurbished buildings. When requirements are set in a separate standard they are less bound by other building rules and require their own enforcement system, which on the one hand might cause complication in the implementation, on the other hand provides much more details to facilitate compliance, thus achieve improvements. Energy certification including energy inspection of buildings, as stipulated by the European Energy Performance in Buildings Directive (EPBD), is one instrument to support building codes. To further tighten this initiative, energy declaration could be required before the construction of the building and 
reviewed after by a third party - consequently the building can be refused to be used until it fulfils the required energy efficiency targets.

There seems to be optimism in the industry around performance certification schemes in line with the recent EPBD directive offers the promise of a stronger market demand for energy efficient buildings. Making visible the energy efficiency of buildings (by certification or labelling) further enhances the enthusiasm of building owners and provides them with competitive advantage on the market. These schemes should also be reliable and controlled by the government and/or public authorities.

\section{Beyond the building code: Promote zero- or near zero-energy buildings}

Building codes set the minimum requirements; however it has been shown in many cases that it is possible and feasible to build with a much higher efficiency. Passive houses and Zero Energy Buildings are such best practice examples. There is, however, a need for better environmental technology verification, which requires clear and well protected standards that distinguish, for instance, "low-energy buildings" or "passive houses" or "zeroenergy buildings” from "conventional” buildings.

The development and diffusion of zero- or near zero-energy buildings needs to be further supported so that they become a competitive option in the market. Policy options to support market creation for these technologies include (1) a well-defined certification as outlined above, (2) investment subsidies to the builder, (3) tax incentives, (4) low-interest loans, (5) technology procurement and provision of public buildings as show-case examples, (6) awareness raising and information provision, e.g. through energy agencies, as well as (7) requirements through municipalities when providing land for construction.

For instance, in Austria, subsidies, which only can be obtained by the owner, who constructs passive or low energy houses, certification schemes for buildings document the passive or low energy house and different promotion initiatives were parts of the policy package, as well as some very active energy agencies. As a result, in Vorarlberg state (Austria) passive houses are now standard for all those buildings receiving a public subsidy.

Passive house standards and/or Zero Energy House standards could also be set as the target for dynamic building codes. It should be again emphasized that this requires a clear and transparent long-term strategy from governments that allows the construction industry to become prepared for future energy efficiency targets.

Demonstrate the leading role of government in public procurement

In the Nordic countries, the public sector is both a major commissioner of new buildings as well as the owner of a significant part of the existing building stock. This provides the public sector with a unique opportunity to promote energy efficient technologies through "green" public procurement, both for new buildings but equally important when refurbishing and upgra- 
ding older buildings. Energy efficient building projects, commissioned by governments can effectively demonstrate to citizens and companies the benefits of innovative technologies in optimizing and reducing the life cycle cost (over a 30 years time period, or ideally over their whole life time).

However, raising awareness and increasing the understanding of energy efficiency and the related cost benefits by education and training of procurement officers as well as removal of administrative barriers is a key prerequisite to the inclusion of clear energy efficiency requirements in all public procurement.

\section{Promote cross-border cooperation}

The building sector in the Nordic countries has operated mostly in a National context. Therefore, increased cross-border cooperation could further facilitate learning, knowledge transfer and information across the Nordic region and eventually enhance the development and diffusion of energy efficient technologies in the Nordic building sector. Concrete support measures may include common Nordic research programmes and technology platforms directed towards the industry. However, international cooperation should not be limited to industry and research. Facilitating cross-border dialogue between policy actors can help in sharing experiences on how to successfully combine different policy mechanisms in supporting markets for energy efficient building technologies.

\subsubsection{Pulp-and-paper sector}

In the past, public polices have influenced environmental innovations in the pulp and paper sector mainly through:

- public R\&D support, funding development projects and encouraging cooperation between different public and private actors;

- investment support and assisting in finding corporate funding for demon-stration projects; and

- policies that encourage competition between different innovative options that include environmental benefits

- The Nordic educational policy has been a crucial prerequisite for success-ful long-term research and has created large pools of technical know-how that has been essential for supporting innovations.

Innovations in the forest sector have the potential to provide further environmental improvements in the form of replacing less harmful chemicals, increasing renewable energy in transport and electricity production, saving energy, providing recyclable products for new product markets, and contribute to waste management along product value chains in other sectors.

In principal, the GMTC report on environmental innovations on the Nordic pulp and paper industry recommends to maintain and further develop 
those policies that have supported environmental innovations in the $\mathrm{P} \& \mathrm{P}$ sector in the past. These are to (1) maintain environmentally conscious highquality education and risk sharing through (2) R\&D support and the inclusion of environmental criteria into research funding grants, (3) direct funding of demonstration projects, (4) risk funding of early company developments, (5) supporting networks for knowledge exchange.

The Forest-Based Sector Technology Platform and the Forest Cluster Ltd have been described as important platforms for public-private partnerships and beneficial in creating visions and action for future innovation. Such platforms should also be linked to other sector technology platforms, e.g. biofuels.

Consistent long-term public policies that reduce the non-technical risks are particularly important for the pulp and paper sector with its long development phases and investment cycles. 



\section{References}

Bauer, B., Larsen, B., Bode,B., Standley, M., Stigh, L. 2008. Technology procurement. TemaNord 2008:567. Copenhagen: Nordic Council of Ministers

Emtairah, T., Tojo, N., Thidell, Å, Rozite, V. and Hayes, M. 2008. The challenges of energy efficiency innovations in the Nordic building sector: Green markets and cleaner technologies (GMCT). TemaNord 2008:566. Copenhagen: Nordic Council of Ministers

Hayes, M. et al. 2008. Innovation Systems and Environmental technologies: Crosssectoral analysis and policy implications. TemaNord 2008:565. Copenhagen: Nordic Council of Ministers International Energy Agency. (2008). Energy efficiency requirements in building codes, energy efficiency policies for new buildings. In support of the G8 Plan of Action. IEA Information Paper.
Jönbrink, A.-K., Melin, H.E. 2008. How central authorities can support ecodesign. TemaNord 2008:569. Copenhagen: Nordic Council of Ministers

Kivimaa, P., Kautto, P., Hildén, M. and Oksa, J. 2008. What drives environmental innovations in the Nordic pulp and paper industry?: Green markets and cleaner technologies (GMCT). TemaNord 2008:566. Copenhagen: Nordic Council of Ministers

Lead Market Initiative for Europe. (2008). Online available: http://ec.europa.eu/ enterprise/leadmarket/leadmarket.htm. Accessed: 10 December 2008

Remmen, A, Dirckinck-Holmfeld, K., Braun, C., Andersen, J., Kræmer, T.-P. The Nordic mobile phone industry - environmental innovations and policy instruments. TemaNord 2008:564. Copenhagen: Nordic Council of Ministers. 



\section{Annex I: Invitation}

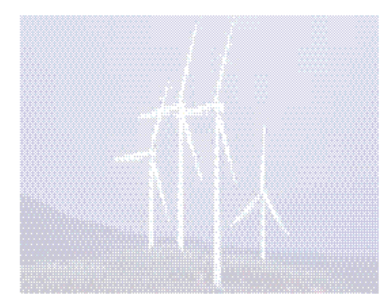

Environmental Technologies and Innovations are at the heart of policymaking in Europe and in the Nordic countries today.

It is the combination of growing competitiveness and excellence on the one hand and environmental gains on the other that provides the potential for success.

The Nordic Council of Ministers Working Group on Integrated Product Policy, NMRIPP, kindly invites You to a Conference on:

\section{Environmental Technology and Innovation - Drivers and Policy Measures \\ 2-3 September 2008 in Bella Center, Copenhagen}

The aim of the Conference is to present and discuss Nordic and global experiences on drivers and challenges for environmental innovations in different sectors and to discuss the role and implication of public policy to facilitate environmental technology and innovation.

The two-day Conference is part of a larger event, COPENMIND, bringing together R\&D, business and policy, and more than 100 top universities and research institutes meet thousands of industry representatives for intellectual and commercial matchmaking on a global scale. For more information about COPENMIND- see www.copenmind.com.

The Conference fee for 40 registered invited attendees will be fully covered by the NMRIPP Working Group. The ambition is to achieve a balanced attendance from all Nordic countries. The fee covers access to COPENMIND's facilities and to the NMRIPP conference. Travel and accommodation are on each participant's own expenses.

You can register for the conference by sending an e-mail to Kerstin Reijs at the Swedish EPA including your name, title, organization and e-mail address. The last day of registration is August 15 2008. Any questions about the conference can be addressed to Stig Hirsbak, stig@hirsbak.dk or by phone +45 46787467.

Registration is binding, any cancellation must be submitted by 20 August, so that the attendance fee may be offered to another interested party. Any cancellation after this date will be subject to a fee of $€ 500$.

Hoping to see you in Copenhagen!

On behalf of the NMRIPP Working Group,

Wnorden

Nordic Council of Ministers

Karin Klingspor, Chair

COPENMIND 



\section{Annex II: Programme}

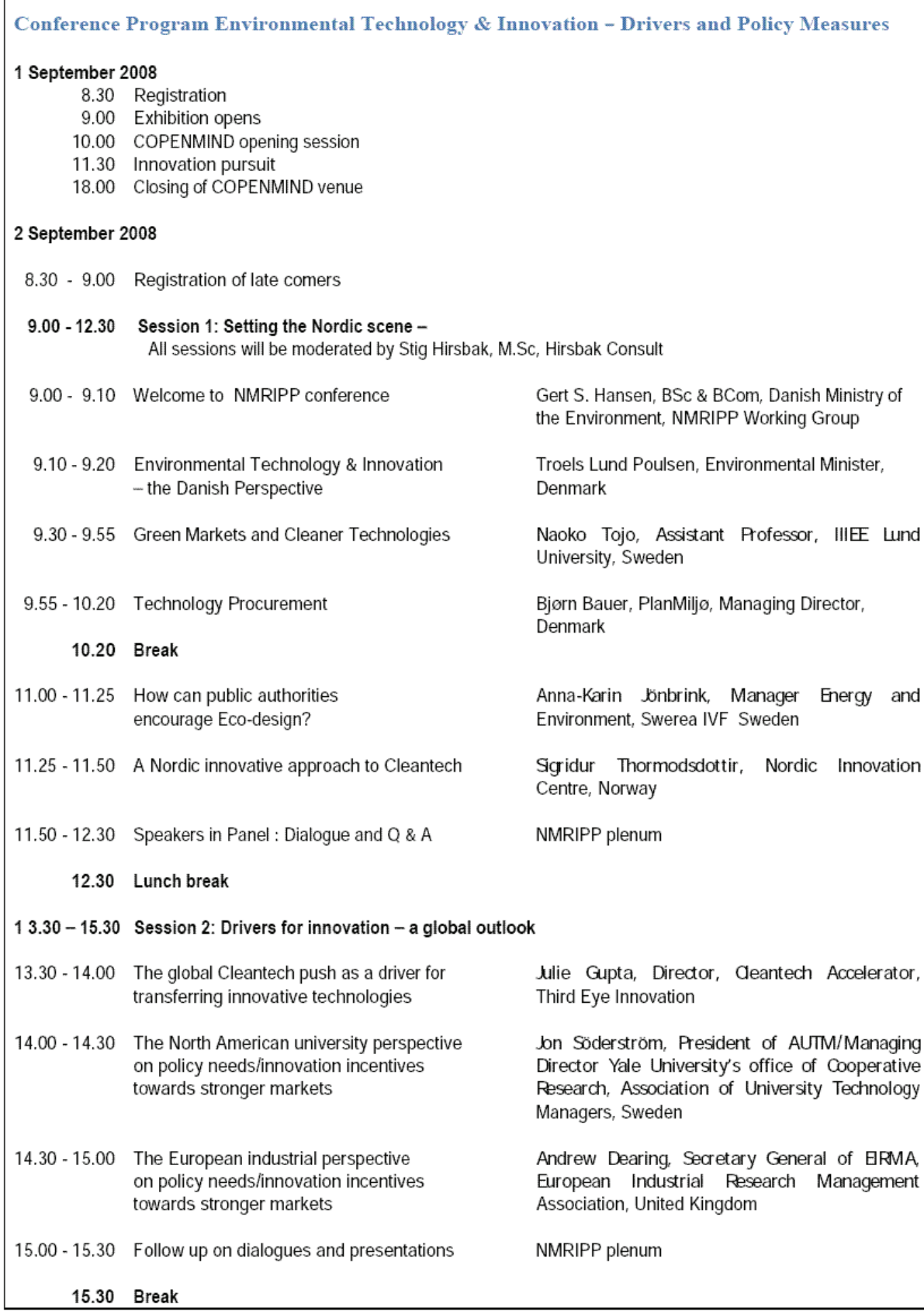




\begin{tabular}{|c|c|c|}
\hline \multirow[t]{2}{*}{$16.00-17.30$} & \multicolumn{2}{|c|}{ Session 3: How do we link environmental policy and innovation? } \\
\hline & \multicolumn{2}{|l|}{ Building sector } \\
\hline $16.00-16.25$ & $\begin{array}{l}\text { The challenges of energy efficiency innovations } \\
\text { in the Nordic building sector }\end{array}$ & $\begin{array}{l}\text { Tareq Emtairah, Research Associate/PhD } \\
\text { Candidate, IIIEE Lund University, Sweden }\end{array}$ \\
\hline $16.25-16.50$ & $\begin{array}{l}\text { WWF's Mindflow session - developing a } \\
\text { method for ranking the world's green cities }\end{array}$ & $\begin{array}{l}\text { Stefan Henningson, Climate Change Director, } \\
\text { WWF, Sweden }\end{array}$ \\
\hline $16.50-17.15$ & Dialogue between speakers and participants & \\
\hline $17.15-17.30$ & Summary and closing remarks of the day & NMRIPP plenum \\
\hline \multicolumn{3}{|c|}{3 September 2008} \\
\hline \multirow[t]{2}{*}{$9.00-12.30$} & \multirow{2}{*}{\multicolumn{2}{|c|}{ Session 3 continued: How do we link environmental policy and innovation? }} \\
\hline & & \\
\hline $9.00-9.25$ & The industrial symbiosis at Kalundborg, Denmark & $\begin{array}{l}\text { John Kryger, Director, Industrial Symbiosis } \\
\text { Institute, Klaundborg, Denmark }\end{array}$ \\
\hline $9.25-9.50$ & $\begin{array}{l}\text { What drives environmental innovations } \\
\text { in the Nordic pulp and paper industry? }\end{array}$ & $\begin{array}{l}\text { Paula Kivimaa \& Naoko Tojo, Researcher, Finnish } \\
\text { Environment Institute }\end{array}$ \\
\hline $9.50-10.30$ & Dialogue between speakers and participants & NMRIPP plenum \\
\hline \multirow[t]{2}{*}{10.30} & Break & \\
\hline & Mobil phone sector & \\
\hline $11.00-11.25$ & $\begin{array}{l}\text { The Nordic mobile phone sector-environmental } \\
\text { innovations and policy instruments }\end{array}$ & $\begin{array}{l}\text { Arne Remmen, Professor, University of Aalborg, } \\
\text { Denmark }\end{array}$ \\
\hline $11.25-11.50$ & An industry case and point of view & $\begin{array}{l}\text { Arja Mehtälä, Director, TP Environmental } \\
\text { Management, Finland }\end{array}$ \\
\hline $11.50-12.30$ & Dialogue between speakers and participants & NMRIPP plenum \\
\hline 12.30 & Lunch break & \\
\hline $13.30-15.30$ & Session 4: Implication for policy makers & \\
\hline $13.30-13.50$ & $\begin{array}{l}\text { Innovation systems and environmental } \\
\text { technologies - Cross-sectoral analysis } \\
\text { and policy implications }\end{array}$ & $\begin{array}{l}\text { Naoko Tojo, Assistant Professor IIIEE, Lund } \\
\text { University, Sweden }\end{array}$ \\
\hline $13.50-14.15$ & $\begin{array}{l}\text { What type of policy instruments are } \\
\text { needed and possible to implement? }\end{array}$ & $\begin{array}{l}\text { Lars Wärngård, Director Competence Areas } \\
\text { Division, VINNOVA, Sweden }\end{array}$ \\
\hline $14.15-15.30$ & Conclusion on findings and key learning points & NMRIPP plenum \\
\hline 15.30 & Next Steps and closing of the conference & $\begin{array}{l}\text { Gert S. Hansen, BSC \& BCom, Danish Ministry of } \\
\text { the Environment, NMRIPP Working Group }\end{array}$ \\
\hline
\end{tabular}




\section{Annex III: Participant list}

\begin{tabular}{|c|c|c|c|c|}
\hline Name & Organization & Email & 2 Sept & 3 Sept \\
\hline Troel Lund Poulsen & Environmental Minister, Denmark & vtlpo@ft.dk & $x$ & \\
\hline Andrew Dearing & $\begin{array}{l}\text { Secretary General of EIRMA, } \\
\text { European Industrial Research } \\
\text { Management Association, UKK }\end{array}$ & adearing@eirma.asso.fr & $x$ & \\
\hline Anette Christiansen & $\begin{array}{l}\text { Erhvervsmiljøchef/Chief Advisor } \\
\text { (Environment) } \\
\text { Erhvervsvilkår/Business Affairs } \\
\text { Landbrugsraadet/Danish Agricul- } \\
\text { tural Council }\end{array}$ & anc@landbrug.dk & $x$ & $x$ \\
\hline Anna-Karin Jönbrink & $\begin{array}{l}\text { Manager Energy and Environ- } \\
\text { ment, Swerea IVF, Sweden }\end{array}$ & anna-karin.jonbrink@swerea.se & $x$ & $x$ \\
\hline Arja Mehtälä & $\begin{array}{l}\text { Director, TP Environmental } \\
\text { Management, Finland }\end{array}$ & arja.mehtala@nokia.com & & $x$ \\
\hline Arne Remmen & $\begin{array}{l}\text { Professor, University of Aalborg, } \\
\text { Denmark }\end{array}$ & ar@plan.aau.dk & $x$ & $x$ \\
\hline Axel Nekham & VINNOVA & axel.nekham@VINNOVA.se & & \\
\hline Berit Gullbransson & Director, Swentec & berit.gullbransson@swentec.se & & \\
\hline Bernadett Kiss & Ginkgo Environmental Consulting & bernadett.kiss@ginkgo3.se & $x$ & $x$ \\
\hline Bjarne Henning Jensen & Partner, Vaeksfonden & bhj@vf.dk & & \\
\hline Bjørn Bauer & $\begin{array}{l}\text { PlanMiljø, Managing Director, } \\
\text { Denmark }\end{array}$ & bb@planmiljoe.dk & $x$ & $x$ \\
\hline Brendan Cook & Ginkgo Environmental Consulting & brendan.cook@mespom.eu & $x$ & $x$ \\
\hline Camilla Sederholm & $\begin{array}{l}\text { Co-ordinator for the Nordic } \\
\text { Council of Ministers working } \\
\text { group for Integrated Product } \\
\text { Policy, MA } \\
\text { Finlands Miljöcentral/Suomen } \\
\text { Ympäristokeskus/Finnish Envi- } \\
\text { ronment Institute }\end{array}$ & camilla.sederholm@miljo.fi & & $x$ \\
\hline Elisabeth Lidbaum & $\begin{array}{l}\text { Näringsdepartementet } \\
\text { Sekretariatet för strategisk } \\
\text { samordning }\end{array}$ & $\begin{array}{l}\text { elisabeth.lidbaum@enterprise. } \\
\text { ministry.se }\end{array}$ & $x$ & \\
\hline Eva Ahlner & $\begin{array}{l}\text { Principal Technical Officer, The } \\
\text { Swedish EPA }\end{array}$ & $\begin{array}{l}\text { eva.ahlner@naturvardsverket } \\
\text {.se }\end{array}$ & $x$ & $x$ \\
\hline Gert S. Hansen & $\begin{array}{l}\text { Miljøteknologi, Miljøministeri- } \\
\text { et//Ministry of Environment } \\
\text { BSc \& Bcom, Danish Ministry of } \\
\text { the Environment, NMRIPP Wor- } \\
\text { king Group }\end{array}$ & gesha@mst.dk & $x$ & $x$ \\
\hline Göran Uebel & $\begin{array}{l}\text { Biträdande utvecklingschefNutek, } \\
\text { Verket för näringslivsutveckling }\end{array}$ & goran.uebel@nutek.se & $x$ & $x$ \\
\hline $\begin{array}{l}\text { Grethe Midgaard } \\
\text { Torrissen }\end{array}$ & $\begin{array}{l}\text { Seniorrådgiver, Miljøverndeparte- } \\
\text { mentet Forurensningsavdelingen }\end{array}$ & grethe.torrissen@md.dep.no & $x$ & $x$ \\
\hline Gunilla Blomquist & $\begin{array}{l}\text { Miljödepartementet (Ministry of the } \\
\text { Environment) } \\
\text { Enheten för hållbar utveckling (Divi- } \\
\text { sion on sustainable development) }\end{array}$ & $\begin{array}{l}\text { gunilla.blomquist@ } \\
\text { environment.ministry.se }\end{array}$ & & \\
\hline Håkan Alm & $\begin{array}{l}\text { Sekretariatet för strategisk sam- } \\
\text { ordning, Näringsdepartementet }\end{array}$ & $\begin{array}{l}\text { hakan.alm@enterprise. } \\
\text { ministry.se }\end{array}$ & $x$ & $x$ \\
\hline Hanne Eriksen & $\begin{array}{l}\text { Director, M.Sc., Ledelse \& } \\
\text { Erhvervsudvikling }\end{array}$ & he@LoE.dk & $x$ & $x$ \\
\hline Hans Henrik Lomholt & $\begin{array}{l}\text { Head of Section, Danish Agency } \\
\text { for Science, technology and } \\
\text { Innovation, } \\
\text { NCP for Environment (including } \\
\text { Climate Change) } \\
\text { NCP for Research Infrastructures } \\
\text { NCP for Regions of Knowledge, } \\
\text { Research Potential \& Coherent } \\
\text { Development of Research Policies }\end{array}$ & hhl@fi.dk & $x$ & $x$ \\
\hline
\end{tabular}




\begin{tabular}{|c|c|c|c|c|}
\hline Name & Organization & Email & 2 Sept & 3 Sept \\
\hline Hans Nilsson & Fourfact AB & hans@fourfact.se & $x$ & $\bar{x}$ \\
\hline Helen Andreasson & $\begin{array}{l}\text { Area Manager of Environmental } \\
\text { and Energy Technology/NINNOVA }\end{array}$ & helen.andreasson@vinnova.se & $x$ & $x$ \\
\hline Helen Bålman & $\begin{array}{l}\text { Project Manager, Baltic } 21 \text { In- } \\
\text { dustry, Environmental Driven } \\
\text { Markets, } \\
\text { Enterprise \& Partner Collaboration, } \\
\text { NUTEK, Swedish Agency for } \\
\text { Economic and Regional Growth }\end{array}$ & helen.balman@nutek.se & $x$ & $x$ \\
\hline Jakob Steen Jensen & $\begin{array}{l}\text { Investment manager - Cleantech } \\
\text { \& Materials, SEED Capital } \\
\text { Denmark }\end{array}$ & jsj@seedcapital.dk & $x$ & \\
\hline Jákup Pauli Joensen, & Director, Environmental Agency, & jakuppj@us.fo & $x$ & \\
\hline John Kryger & $\begin{array}{l}\text { Director, Industrial Symbiosis } \\
\text { Institute, Kalundborg, Denmark }\end{array}$ & john@symbiosis.dk & & $x$ \\
\hline Jon Söderström & $\begin{array}{l}\text { President of AUTM/ Managing } \\
\text { Director, Yale University's office of } \\
\text { Cooperative Research, Associati- } \\
\text { on of University Technology } \\
\text { Managers, Sweden }\end{array}$ & jon.soderstrom@yale.edu & $x$ & \\
\hline Jørgen Schou & Miljøteknologi, Miljøstyrelsen & js@mst.dk & & \\
\hline Julie Gupta & $\begin{array}{l}\text { Director, Cleantech Accelerator, } \\
\text { Third Eye Innovation }\end{array}$ & julie.gupta@cleantech.com & $x$ & \\
\hline $\begin{array}{l}\text { Kasper R. } \\
\text { Dirckinck-Holmfeld }\end{array}$ & Ecoinnovation & kadir@mst.dk & $x$ & \\
\hline Lars Strupeit & Ginkgo Environmental Consulting & lars.strupeit@ginkgo3.se & $x$ & $x$ \\
\hline Lars Wärngård & $\begin{array}{l}\text { Director Competence Areas } \\
\text { Division, VINNOVA, Sweden }\end{array}$ & lars.warngard@vinnova.se & & $x$ \\
\hline Lotte Kau Andersen & $\begin{array}{l}\text { Chemical Engineer, Miljøstyrel- } \\
\text { sen/Danish EPA } \\
\text { Miljøteknologi/Ecoinnovation }\end{array}$ & lka@mst.dk & $x$ & $x$ \\
\hline Maj Munch Andersen & $\begin{array}{l}\text { Senior scientist, Department of } \\
\text { Management Engineering, } \\
\text { Technical University of Denmark }\end{array}$ & maj.munch.andersen@risoe.dk & & $x$ \\
\hline Mariane T. Hounum & $\begin{array}{l}\text { Civilingeniør, Miljøstyrelsen } \\
\text { Klima og Miljøteknologi }\end{array}$ & mth@mst.dk & $x$ & \\
\hline Martin Flack & $\begin{array}{l}\text { Institutet för tillväxtpolitiska studier } \\
\text { (ITPS) } \\
\text { The Swedish Institute for Growth } \\
\text { Policy Studies }\end{array}$ & martin.flack@itps.se & $x$ & $x$ \\
\hline Merja Saarnilehto & $\begin{array}{l}\text { Senior Adviser, Ministry of the } \\
\text { Environment, Finland }\end{array}$ & merja.saarnilehto@ymparisto.fi & $x$ & $x$ \\
\hline $\begin{array}{l}\text { Michael Søgaard } \\
\text { Jørgensen }\end{array}$ & $\begin{array}{l}\text { Associate Professor and Science } \\
\text { Shop Coordinator, } \\
\text { DTU Management Engineering } \\
\text { Technical University of Denmark } \\
\text { (DTU) }\end{array}$ & msj@ipl.dtu.dk & & $x$ \\
\hline Naoko Tojo & $\begin{array}{l}\text { Associate Professor, IIIEE, Lund } \\
\text { University, Sweden }\end{array}$ & naoko.tojo@iiiee.lu.se & $x$ & $\mathrm{x}$ \\
\hline Nils Hune & $\begin{array}{l}\text { Danish Enterprise and Construc- } \\
\text { tion Authority }\end{array}$ & nh@ebst.dk & & \\
\hline Nis Christensen & $\begin{array}{l}\text { The Confederation of Danish } \\
\text { Industry }\end{array}$ & nch@di.dk & $x$ & \\
\hline Östen Ekengren & $\begin{array}{l}\text { Vice V.D - IVL-Svenska Miljöinstitu- } \\
\text { tet AB }\end{array}$ & osten.ekengren@ivl.se & $x$ & \\
\hline Per Sander Døvle & $\begin{array}{l}\text { Deputy Director, Norwegian } \\
\text { Pollution Control Authority (SFT) }\end{array}$ & per.dovle@sft.no & $x$ & $\mathrm{x}$ \\
\hline Pirjo Kaivos & $\begin{array}{l}\text { Group Manager, M.Sc. (Eng.), } \\
\text { Environment } \\
\text { The Federation of Finnish Tech- } \\
\text { nology Industries }\end{array}$ & pirjo.kaivos@techind.fi & $x$ & $x$ \\
\hline Ragnar Heldt Nielsen & $\begin{array}{l}\text { Managing Director, GTS - } \\
\text { Advanced Technology Group }\end{array}$ & rhn@gts-net.dk & $x$ & \\
\hline Rikke Traberg & Miljøstyrelsen, Miljøteknologi & ritra@mst.dk & $x$ & \\
\hline $\begin{array}{l}\text { Sigridur } \\
\text { Thormodsdottir, }\end{array}$ & $\begin{array}{l}\text { Nordic Innovation Centre, Nor- } \\
\text { way }\end{array}$ & $\begin{array}{l}\text { sthormodsdottir@ } \\
\text { nordicinnovation.net }\end{array}$ & $x$ & \\
\hline Silke Alsen, & NETS, Nordic Innovation Centre & silke.alsen@grontmij-carlbro.dk & $x$ & $x$ \\
\hline Sissel Klingenberg & Klar Tale & siskling@klartale.net & $x$ & $x$ \\
\hline
\end{tabular}




\begin{tabular}{|c|c|c|c|c|}
\hline Name & Organization & Email & 2 Sept & 3 Sept \\
\hline Stefan Henningson & $\begin{array}{l}\text { Climate Change Director, WWF, } \\
\text { Sweden }\end{array}$ & stefan.henningsson@wwf.se & $\mathrm{x}$ & \\
\hline Stig Hirsbak & Stig Hirsbak Consulting & stig@hirsbak.dk & $x$ & $x$ \\
\hline Synnøve Bjørke & $\begin{array}{l}\text { Administreredne Direktør/CEO } \\
\text { Elektronikkbransjen, Consumer } \\
\text { Electronics Trade Foundation }\end{array}$ & sb@elektronikkbransjen.no & & $x$ \\
\hline Tareq Emtairah & $\begin{array}{l}\text { Research Associate/ PhD Can- } \\
\text { didate, IIIEE, Lund University, } \\
\text { Sweden }\end{array}$ & tareq.emtairah@iiiee.lu.se & $x$ & \\
\hline Ulf E. Andersson & $\begin{array}{l}\text { Naturvårdsverket, Enheten för } \\
\text { investeringsprogram } \\
\text { Avdelningen för hållbar samhäll- } \\
\text { sutveckling }\end{array}$ & $\begin{array}{l}\text { ulf.andersson@ } \\
\text { naturvardsverket.se }\end{array}$ & & \\
\hline \multicolumn{5}{|c|}{ Additional participants } \\
\hline Andreas Halvarsson & $\begin{array}{l}\text { Ministry of Entreprise, Energy } \\
\text { and Communication, Sweden }\end{array}$ & $\begin{array}{l}\text { Andreas.halvarsson@ } \\
\text { enterprise.ministry.se }\end{array}$ & $x$ & \\
\hline Sven-Eric Hargeskog & $\begin{array}{l}\text { Senior Procurement Advisor, } \\
\text { Vinnova, Sweden }\end{array}$ & $\begin{array}{l}\text { sven.eric.hargeskog@ } \\
\text { vinnova.se }\end{array}$ & $\mathrm{x}$ & $x$ \\
\hline Alesia Israilava & IIIEE, Lund University & alesia.israilava@mespom.eu & $x$ & $x$ \\
\hline Ulf Burman & $\begin{array}{l}\text { IVL, Swedish Environmental } \\
\text { Institute }\end{array}$ & ulf.burman@ivl.se & $x$ & \\
\hline Pouline Middleton & $\begin{array}{l}\text { Managing director, Crossroads } \\
\text { Copenhagen }\end{array}$ & pm@crossroadscopenhagen.dk & $x$ & \\
\hline Bent Søndergård & Roskilde University & bents@ruc.dk & $x$ & \\
\hline Jørgen Hvid & Senior Advisor, Ramboll & jhv@ramboll.dk & & $x$ \\
\hline Charlotte Trap-Kinberg & & ctk@pwc.dk & & $x$ \\
\hline Silvia Ceansu & IIIEE, Lund University & silvia.ceansu@mespom.eu & & $x$ \\
\hline Jyri Rantanen & IIIEE, Lund University & jyri.rantanen@mac.com & & $x$ \\
\hline Marianna Bofakou & Ministry of Development, Greece & mabo@gsrt.gr & & $x$ \\
\hline
\end{tabular}





\section{Annex IV: Presentations}

1. Green Markets and Cleaner Technologies (Naoko Tojo)

2. Technology Procurement (Bjørn Bauer)

3. How can public authorities encourage Eco-design?

(Anna-Karin Jönbrink)

4. A Nordic innovative approach to Cleantech (Sigridur Thormodsdottir)

5. The global Cleantech push as a driver for transferring innovative technologies (Julie Gupta)

6. The North American university perspective on policy needs/innovation incentives towards stronger markets (Jon Söderström)

7. The European industrial perspective on policy needs/innovation incentives towards stronger markets (Andrew Dearing)

8. The challenges of energy efficiency innovations in the Nordic building sector (Tareq Emtairah)

9. WWF's Mindflow session - developing a method for ranking the world's green cities (Stefan Henningson)

10. The industrial symbiosis at Kalundborg, Denmark (John Kryger)

11. What drives environmental innovations in the Nordic pulp and paper industry? (Paula Kivimaa \& Naoko Tojo)

12. The Nordic mobile phone sector-environmental innovations and policy instruments (Arne Remmen)

13. Environmental Technology and Innovation - Motivation and examples in mobile devices (Arja Mehtälä)

14. Innovation systems and environmental technologies - Cross-sectoral analysis and policy implications (Naoko Tojo)

15. What type of policy instruments are needed and possible to implement? (Lars Wärngård) 



\section{Annex V: Conference papers}

\section{How can public authorities encourage Ecodesign?}

Anna Karin Jönbrink, Swerea IVF

This paper is based on the summary of a study financed by the Nordic Council of Ministers and called "How central authorities can support ecodesign, company perspectives”. The study was carried our by Anna Karin Jönbrink, Swerea IVF, ecodesign expert, and Hans Eric Melin, Ivy Communications, communications and environment expert. Methodology used in the study was a combination of a literature survey, an interview research where 16 companies from different industries were interviewed in depth, and workshops to put it all together. The final report of the study is available at www.norden.org/pub.

Over the years, ecodesign - that is the process of integrating environmental aspects into product development and design using a life-cycle perspective has gained a lot of interest from both companies and authorities. From a company's point of view, the interest comes from the hope to gain competitive advantages. Public policy makers and authorities foremost see the potential for decreasing environmental and health impact from products and contribution to sustainable consumption.

The purpose of this study is to give suggestions foremost to central authorities on what can be done by them in order to further support and strengthen the practise and use of ecodesign among enterprices.

Although there are several success stories of ecodesign, it's fair to say that ecodesign not yet has reached a general acceptance among enterprises. By using companies own experiences, this study identifies incentives and barriers for ecodesign as well as company structures on what really drives companies to use ecodesign.

The findings indicate that the concept of ecodesign is not as strong as its content. Companies with leading positions in a wide range of industries work actively to lower their environmental impact, but the main incentive is only occasionally aimed at environmental issues. Instead they aim at decreasing other product features such as its weight and energy use, as well as other product changes wanted by the customers. In fact, a main finding in this study is that there are from a company perspective no actual incentives for the concept of ecodesign. However, instead, there are incentives for product development and design, either because there are problems to be solved or opportunities to be exploited. 
The study showed clearly that the main incentives for developing new products is increased sales, as well as maintained or increased market share. Product development is rarely aimed at decreasing the companies' own costs. This is supported in literature stating that companies that use a 'focus strategy' (concentrate on a specific segment) or a 'differentiation strategy' (making their products unique) should pay less attention to low price and more focus on adding new features that can motivate a premium to and around the product. This implies that if ecodesign should be used in these companies, the result of it should be to add value to their products.

What's interesting is that most companies in the study said they could do more for the environment but saw little incentive to do so. Regulations and laws often aim too low. Thus, all market players will offer the same environmental benefits and giving customers no added incentive to buy better products. Even if not all companies are explicitly asking for tougher legislation, it is likely that more ambitious companies would benefit, while others would be forced to improve.

This is also especially true in public procurement, a sequence many companies find everything but "green", and there should be better enforcement of environmental policy as well as use of environmental criteria. As long as public organizations do not buy best possible products for the environment, a big market is wasted from a societal point of view. And as long as price is more important than the environment, this is also a message to all companies about what really counts.

A main barrier to ecodesign for companies is to overcome is product development costs. Even if companies do not consider general ecodesign features as vital to their customers, developers and marketers see a potential in selling their products with new values or even to new customers. However, this means high risk and takes financial as well as personal resources from activities that otherwise would be used to keep pace with their competitors.

The interviewees were more positive towards legislation and regulation than expected. It was obvious that companies providing environmentally good products see stricter legislation as a positive thing, making their competitors work even more to fulfil them. For some issues, such as chemical substances where it is possible that the customers do not have enough knowledge to make demands, legislation is seen as the only way to improve the products.

Companies not already providing environmentally good products see legislation as the only reason to improve their products, asking "why should we use money and effort to create something which is not asked for by anyone?” They think that if a law tells them what to do, it is the same for their competitors. But if they do it unilaterally, they only see a cost that the competitors don't have. The recommendations are therefore to let best practice guide legislation. Weak legislation gives legitimacy to lagging companies, while it doesn't encourage good companies to do better. Doing this, it is also important for authorities to have contacts with individual companies rather 
than industry associations, as the latter normally represent the middle or lower range, rather than the top.

To increase the possibilities for developing ecodesign even without an obvious or in an unpredictable market, support for research, development and marketing can be success factors. However, for this to be effective the support should be flexible and long-term. Instead of stating in detail what companies should develop from an authority perspective, definitions should be broader. The demands should include the likelihood of whether the company will succeed, not only with the development, but also with commercialization of the product. A key feature here is also to enable companies to use ecodesign principles within their current product strategy.

Finally, there is a need for more easy-to-use tools for ecodesign and its different processes. This is not considered as a main barrier, but everything that can make knowledge more accessible and the work smoother will be positive for the development of ecodesign.

\section{Technology Procurement}

\section{Bjørn Bauer, PlanMiljø ApS}

Eco-Innovative Procurement aims at combining the concepts of Ecofriendliness and Innovation into a future oriented range of procurement approaches - with Technology Procurement expressing the most advanced methodology.

Historically, technology procurement dates back at least 250 years. In 1713, the English "Longitude Act" offered a prize of 20,000 pounds for a method to determine longitude, and in 1773 John Harrison was awarded the prize for his portable chronometer.

In a Nordic context technology procurement has been exercised primarily in Sweden especially with the purpose to speed up the market introduction of energy-efficient products.

Successful examples of technology procurement can be identified in individual countries and in international cooperation, embracing a variety of technologies and products such as household and commercial appliances, lighting systems, building components, and office and industrial equipment. Evident environmental and economic benefits have been achieved and innovation supported.

\section{What is Technology Procurement}

Technology procurement is a bidding process that stimulates and enhances the development and market introduction of an article or a service nonexistent on the market, requiring development to fulfil the purchasers' objectives and demands. Technology procurement may include procurement 
stimulating the market development of existing products that have very low/non-existent market penetration.

Innovative procurement has three major focus areas:

- Supplier development (e.g. products, distribution and support);

- Buyer development (e.g. new ways of using the products, new budget rules for allowing innovative procurement decisions, new administrative rules for motivating effective use of products);

- Regulatory development (i.e. changing the regulatory structure to allow new products, usages, etc.)

\section{Heat pumps}

The first Swedish technology procurement process targeting small houses focused at heat pumps. A pre-study concluded that technology development in the heat pump business was weak and that there was a need to replace oil and traditional electricity heating with more energy efficient heating techniques. The purchaser group consisted of property owners, energy suppliers, energy service companies, Norwegian Water Resource and Energy administration (NVE), NUTEK and the Swedish Testing and Research Institute. The national Swedish Board and Motiva in Finland were passive members.

An international tender resulted in 23 offers of which ten were granted 50,000 SEK and further evaluated by Vattenfall and the Swedish Testing and Research Institute. The two winners, each receiving 300,000 SEK, met the targets of 30\% less energy consumption, $30 \%$ cheaper and no halogens in the cooling media. The first hundred buyers received a discount of 3,000 SEK. Two dedicated NUTEK technicians promoted the new product through an information campaign, seminars, a brochure, articles and energy/house exhibitions, causing a huge increase in heating pump sales figures.

Technology procurement is not supposed to raise sales volumes of existing products but rather to drag the market in a desired direction by introducing new technology. Some might argue that the technology would have been introduced later on anyway. This may in some cases be true. However, by leapfrogging ahead and introducing the technology at an earlier stage benefits are gained sooner.

With technology procurement, information about specific needs and demands from potential purchasers is conveyed in an organised way to the potential suppliers. Typically, technology procurement processes have aimed at fragmented markets with many buyers and many (potential) suppliers. 


\section{The steps of technology procurement}

Although technology procurement exists in many varieties some generic steps of the process can be identified. The model used with success by the Swedish Energy Agency includes the following steps:

- Selection of target area

- Pre-study or feasibility study

- Creation of a buyer group

- Formulation of specifications

- Tendering process

- Evaluation of tenders

- Spreading of information

- Further development

\section{Selection of target area}

Selecting the right target area or product group for technology procurement is crucial to harvest the best possible innovative and environmental benefits of the resources available. The selection process should not focus too narrowly on just developing new technology but include new products, new services, products adapted to new markets, increased product availability and development of new distribution systems.

Technology procurement requires that the demanded volume is large enough to stimulate the suppliers given the current state of technology - i.e. the bigger the step to be taken, the greater the volume required ${ }^{8}$. This usually implies that a central decision-making authority should be in place and motivated for technology procurement.

\section{Pre-study or feasibility study}

The initiator conducts a feasibility study with examination of the technology and market prospects for the specific functional needs. A considerable potential for innovation and environmental improvements should be identified to allow for sufficient benefits from the technology procurement process. In addition there must be significant indications of a future market demand for the new (or improved) products. Those who initiate the process should have a clear plan of how demand can be stimulated (e.g. through marketing campaigns) to an extent sufficient to attract the potential manufacturers' interest.

A definition of the supply chain enables the initiators to target information to relevant decision makers and market actors.

\footnotetext{
${ }^{8}$ With the right incentives for the manufacturers, a technology procurement process may also be launched for a smaller volume of products aiming at a catalytic effect
} 
Gas driven ferries, Norway

Most of Norwegian ferry services are run by private companies and purchased by the Norwegian Public Roads Administration (NPRA) on an open competitive basis for a specified time period (usually ten years). The ferry services contribute significantly to the considerable emission of NOx from Norwegian shipping.

A small ferry fuelled by Liquefied Natural Gas, LNG, was put into operation in 2002 and demonstrated an $80 \%$ reduction in NOx and 15-25\% less $\mathrm{CO}_{2}$-emissions compared to conventional diesel fuelled engines. The challenge was to develop and introduce the necessary technology and supply chains for running full-sized ferries.

In April 2004, the NPRA issued a request for tender for ferry services based on LNG fuel (single fuel). This was a competitive procurement open for negotiation. One manufacturer accepted to cover the development costs for the new marine engines in view of the volume of the contract (16 engines). A third supplier was willing to take the responsibility for the supply of LNG, as the ferry contract implied a mainstreaming of business that allowed for significant expansion - especially on the production side.

The ferries were delivered in 2006 and 2007 and a new contract has been signed for operation of three new ferries for the period 2010-2019 further North on the Western Coast of Norway.

The process has included:

- $\quad$ Development of new products (marine LNG engines)

- New design methodology for passenger ships (safety considerations)

- Establishment of new production and distribution facilities for LNG

- Legislative changes.

Other actors are now taking the technology into use. The results have been achieved without direct public subsidies, although it is unclear whether the price that the NPRA has to pay for LNG-fuelled ferry services is higher than diesel or not.

\section{Creation of a buyer group}

The main issues of this phase are the identification of motivated buyers, the capability of them to act as a group and the influence they represent in the market.

A group of well-informed and influential purchasers form a "buyer group" with an aggregated demand for the new product. The larger and more influential the buyer group, the more incentives they create for manufacturers to participate. However, a large buyer group is not necessarily a crucial factor, as also for example a smaller group of market leaders can constitute an influential buyer group. For suppliers, one of the most important aspects is the prestige and the market recognition attained from winning a procurement competition based on the specifications of those leading buyers.

The procurers must be willing to face the specific challenges connected with the technology procurement process, including: 
- Economic

- Price uncertainty

- Unclear cost of the procurement process itself

- Uncertain operational costs

- Timely delivery/quality

- Risk of not getting many (or even any) qualified offers

- Manufacturers not being able to satisfy the demand in time

- Administrative

- Internal and external rules/regulations may need to be adapted

- Increased risk of reactions from non-selected suppliers

- Need for organisational development incl. training

- Competences

- Increased requirements to procurers' technical knowledge

- Complex procurement process

Few procurement officers will deal with these uncertainties without being guided by strong political leadership and high-level willingness to accept the risks and challenges mentioned.

\section{Formulation of specification}

In this phase, the buyer group formulates product specifications with the help of technical experts. The most useful specifications are often the more simple ones, building on sound technical knowledge of what is technically feasible without large investments in research and development slowing the pace. The difficult task appears to be reaching consensus on the precise buyers' expectations of the new product, expressed as rigid functional specifications (mandatory or desired) without specifying the use of a particular technology.

Moreover, even if the aim is to have more efficient products entering the marketplace, all other product features are equally important to make the product acceptable - and desirable - for the end user. Examples of such features are noise level, aesthetic design, user friendliness and, of course, low life-cycle costs.

This phase also include identification of assessment parameters and procedures for the evaluation of manufacturers' bids.

\section{Tendering process}

The tendering process should at the same time be precise and ambitious and allow as many potential manufacturers as possible to participate to ensure maximum quality of the process.

One of the most powerful incentives for manufacturer participation is commitment from the buyer group to a certain sized order of the new product. In most cases the buyer group does not make any legally binding 
commitments to buy a specific number of products. Rather it is the credibility of the buyer group and the suppliers' confidence in the commitment of the buyers that have motivated the suppliers to bid.

The invitation to tender must be clear and precise and include all necessary information regarding specifications, prices, awards, evaluation criteria and rules, along with marketing conditions for the winner(s). The tendering period must be long enough in the light of product complexity for the manufacturers to develop prototypes and submit their bids.

\section{Evaluation of tenders}

The evaluation of tenders may include prototype testing and measurements. It is of great importance that the evaluation be performed by an independent jury or similar group and that this is specified in the invitation to tender. The winner(s) will be selected according to the evaluation criteria already specified in the invitation to tender.

Awards can take many shapes. In some instances, it is sufficient for the suppliers to win the opportunity to have their newly developed products tested and used by competent buyers, who can give feedback. In other cases, the volume of units delivered helps reduce risk for a manufacturer when starting serial production. Formal awards of excellence, as well as press releases, demonstration projects and marketing campaigns are other important tools.

One way of risk-minimisation is to use award criteria ("should") rather than technical specifications ("must”). Evaluation and weighting of such criteria is complex, therefore capacity building of procurement officers is necessary.

\section{Spreading of information and further development}

The value of the process is not primarily related to the success of the specific product developed but rather to total market transformation. Publicity, along with follow-up activities, is necessary to multiply the success and maximise the impact of the process in the market. The winner's achievements must be spread to the market, and the new technical solution developed and benefits from its application must be widely known.

\section{Technology Procurement - the organisational set-up}

Technology procurement entails interesting perspectives for combining the large expenditure on public procurement with the need for environmental improvements, constant innovation and development of the business sector. Experience demonstrates that considerable socio-economic and environmental benefits can be achieved with use of this approach if resources are allocated and the organisational elements are in place. This section briefly descri- 
bes an effective institutional framework spiced with examples from the Nordic countries.

\section{Leadership}

By undertaking the role as national focal institution for innovative green procurement, a dedicated institution - be it a national procurement organisation, a state department or another national or sub-national entity - can ensure the necessary focus on the long-term goals and support proper organisation of each technology procurement process. The focal institution should function as an operative agent with resources in the form of time, money, and competent staff.

The most visible technology procurement institution in the Nordic countries has been NUTEK in Sweden, but also Motiva in Finland has played an important role in the national context.

Leadership means in this context not least accepting the risks associated with departing the beaten track. Procurement officers will not engage themselves in technology procurement without clear messages and support being expressed from a superior authority.

Among the tasks of the focal institution are:

- Formulate, disseminate and promote the vision.

- Induce dialogue between institutions and stakeholders on how to tagerget the vision.

- Promote establishment of user and purchaser groups enabling technology procurement, i.e. setting up buyer groups.

- Launch technology procurement projects and stimulate and support technology procurement processes in other institutions.

- Ensure compilation and dissemination of good practice, including networking events.

- Address legal issues and develop guidelines or handbooks for procurement officers on how to minimise legal risks.

- Participate in international networks to ensure compilation and dissemination of good practice at international level, e.g. the International Energy Agency's working groups.

- Participate and support other institutions' participation in international technology procurement projects - e.g. the Energy+ projects.

\section{Vision - political signals}

An explicit national vision expressing themes such as sustainability and greening of the public sector should draw the attention of institutions and individuals in the direction of innovative procurement. Technology procurement fits perfectly into a national development context aiming at innovation of environmentally sound technologies and a general greening of the 
society through implementation of such technologies. Such strategies and plans exists in most countries, an example is the 2007 Danish National Action Plan for Environmental Technologies (which for the moment does not deal with technology procurement). As recommended by NUTEK $^{9}$, it is important to see technology procurement as part of an overall policy for public procurement and innovation.

By streamlining innovation and environment in public procurement, procurement staff (normally focused on reducing the cost of procurement) may proactively utilise the opportunities for playing a more dynamic role in society. The present efforts of the Finnish working group on technology procurement may lead in this direction.

Technology procurement is mentioned in several Swedish acts as a means to achieve environmental improvements. As in Sweden the vision could be institutionalised through inclusion in the legislative framework in the other Nordic countries. The Norwegian Action Plan for Environmentally and Socially Responsible Procurement specifies that further measures for stimulation of technology procurement should be considered, and the Norwegian Panel for Green Public Procurement has established a working group on the theme of Public Procurement and Innovation.

\section{Strategy}

A road map for the inclusion of innovative environmental considerations in public procurement is necessary to most effectively pursue the vision and overall goals. With specific objectives and associated actions, the strategy elucidates the amount of resources allocated to this work field, motivates stakeholders and enables meaningful evaluation of the efforts.

The strategy may deal with, among others, the following areas of action:

- Prioritisation of target areas and sectors

- Investigation of purchaser needs

- Investigation of effects on the procurement process

- Training needs

- Pilot projects

- Risk mitigation

\section{Structure}

The structure should provide a framework for public buyers enabling them to be innovative in the purchasing process. The technology procurement examples demonstrate that at least the following positions should be filled:

\footnotetext{
${ }^{9}$ Reference: Offentlig upphandling som drivkraft för innovation och förnyelse, Redovisning av regeringsuppdrag, R2006:21, NUTEK
} 
- An active and competent purchaser group

- Facilitator and project manager - technology procurement projects are long lasting (2-4 years) and involve many partners, why skilled project management and facilitation is needed.

- Experts responsible for feasibility studies and other background investigations

- Purchaser group members

- Contact person to suppliers

\section{Personnel}

One of the most important factors for successful innovative procurement strategies is a motivated and competent staff. Motivation among procurement officers can be achieved by applying a participatory approach when conducting technology procurement projects. A clear and communicated vision for the use of technology procurement is also an important factor for motivation.

With the exception of Sweden public purchasers and personnel in Nordic organisations have little or no knowledge about technology procurement. A training programme for public purchasers and other relevant personnel is a prerequisite for expanding the use of technology procurement.

One of the tasks of the focal institution is risk handling. Addressing legal and economic risks is crucial in order to motivate the procurement officers to use technology procurement. The risk of using an unknown or unfamiliar methodology is a barrier that must be overcome through strong leadership and support, but also through training and pilot projects. Relevant themes for capacity building include each of the steps of technology procurement as described above, but also risk handling and economic and legal issues associated with the methodology.

\section{Systems}

Implementation of expedient systems will ease the process of innovative procurement and ensure a certain harmonisation of the national or even supra-national approach. The technology procurement methodology itself constitutes the overall system; specific development of each element of the procurement process will increase effectiveness of technology procurement and reduce the risks and uncertainties connected with the process. Relevant systems include guidelines, case stories, good practises and tools.

\section{Culture}

Creation of a culture promoting innovative green procurement requires a long lasting effort during which leadership and communication are of vital importance. One sign of such a culture is when communication of specific needs 
and demands from buyers to potential developers and producers has become institutionalised and normal practice. In Iceland the tradition of close cooperation has been formalised and developed into the concept of technology forums. In Denmark the tradition of cooperation is weaker, even though experiences exist with in the Electricity Savings Trust. The lack of tradition - or reluctance towards public-private cooperation - is an obstacle for increased use of technology procurement that must be actively dealt with.

Another cultural issue is the question of procurement officers' loyalty to processes and framework agreements in decentralised cultures as in the Nordic countries. Genuine implementation of the technology procurement strategy requires continuous focus on the organisations' and the individuals' ability and will to act as desired. 